\title{
Antioxidant Content Determination in Ripe Date Fruits (Phoenix dactylifera L.): a Scoping Review
}

\author{
Nora Abdullah AlFaris ${ }^{1} \cdot$ Jozaa Zaidan AITamimi $^{1} \cdot$ Lujain Abdulaziz AIMousa $^{1} \cdot$ Fatima Ali AIGhamidi ${ }^{1}$. \\ Riyadh A. Alzaheb ${ }^{2}$ - Najla Abdullah Albaridi ${ }^{1}$ (D)
}

Received: 8 July 2020 / Accepted: 27 November 2020 / Published online: 6 January 2021

(C) The Author(s) 2021

\begin{abstract}
Ripe date fruits are a rich source of antioxidants. The current scoping review was conducted to identify various characteristics of studies that were carried out to determine antioxidant content in ripe date fruits. The framework established by Arksey and O'Malley was adopted to conduct this scoping review. The Preferred Reporting Items for Systematic Reviews and Meta-Analysis extension for Scoping Reviews (PRISMA-ScR) was used as a guide during the review process. Relevant studies published in March 2019 or any time before were retrieved from three databases. Study selection was performed based on specific inclusion criteria. The extracted data from selected studies were organized in a charting table, and then analyzed using descriptive statistics. A sum of thirty-one articles were selected and included in the present scoping review. Various characteristics of the selected studies, collected ripe date fruit samples, and extraction solvents, as well as information about determining antioxidant content and the used analytical methods, citation references for procedures, measurement units, and data presentation methods, have been identified and discussed carefully. High inconsistency and variability were observed among the selected studies. The research gaps and future recommendations to promote higher research design consistency and improve research quality in this area of research have been described.
\end{abstract}

Keywords Scoping review $\cdot$ Antioxidant content $\cdot$ Determination $\cdot$ Ripe $\cdot$ Date fruits

\section{Introduction}

The date palm (Phoenix dactylifera L.) is an important fruit crop with over than two thousand date cultivars which are grown worldwide, especially in the Middle East and North Africa (Chao and Krueger 2007). Date fruits pass through several ripening stages, reaching to full ripeness. These stages include Hababouk, Kimri, Khalal or Besser, Rutab, and Tamer. Tamer stage is the last stage of ripeness where date fruit becomes mature with brown or black color, and relatively higher sugar and lower moisture contents (Hussain et al. 2020). Date fruits are a nutritionally rich food and considered a good source for carbohydrates, including simple sugars and

Najla Abdullah Albaridi

naalbaridi@pnu.edu.sa

1 Department of Physical Sport Science, Princess Nourah bint Abdulrahman University, P.O. Box 84428, Riyadh 11671, Saudi Arabia

2 Department of Clinical Nutrition, Faculty of Applied Medical Sciences, University of Tabuk, Tabuk, Saudi Arabia dietary fiber, vitamins such as ascorbic acid, thiamine, and riboflavin, and minerals such as iron, potassium, and phosphorus (Al-Shahib and Marshall 2003; Al-Farsi and Lee 2008). Date fruits have several beneficial health effects, including antimutagenic, antihyperlipidemic, antimicrobial, anti-inflammatory, hepatoprotective, nephroprotective, and gastroprotective activities (Baliga et al. 2011; Tang et al. 2013).

Antioxidants are biologically active compounds able to quench reactive free radicals, such as hydrogen peroxide, superoxide radical, and hydroxyl radical. Thus, they can prevent or slow down body cell damage caused by free radicals (Lee et al. 2004; Liu et al. 2018). Therefore, antioxidants play a vital role in human health as they decrease the risk of many chronic diseases such as cancers, cardiovascular disease, neurodegenerative disorders, liver cirrhosis, atherosclerosis, and diabetes (Neeraj et al. 2013; Barros 2020). In fact, date fruits have high antioxidant properties due to their high content of vitamins such as ascorbic acid and tocopherols, and phytochemicals such as polyphenols and carotenoids (Al-Farsi et al. 2018; Al-Shwyeh 2019; Hussain et al. 2020). Phenolic compounds exhibit an extremely high antioxidant activity 
(Maqsood et al. 2020). The antioxidant activity of the date fruits refers largely to its phenolic compounds, including gallic, p-coumaric, ferulic, syringic, and caffeic acids, and flavonoid compounds, including rutin, quercetin, quercetin, isoquercetrin, and apigenin (Hong et al. 2006; Biglari et al. 2008; Benmeziane-Derradji 2019).

Considering the high nutritional value of date fruits, studying their antioxidant content is progressively being increased (Kchaou et al. 2014). Numerous factors have been verified to be responsible for the variances in antioxidant content of date fruits such as cultivar type, ripening stage, growing conditions, season, geographic location, fertilizer, type of soil, storage periods, and quantity of sunlight received (Al-Farsi et al. 2007; Al-Mssallem et al. 2020). Gathering detailed information about antioxidant content of various date fruit cultivars could help to reach a better understanding of their healthpromoting properties. Unfortunately, the high inconsistency and variability in research designs appear in the studied literature and this area limits their result impact and implications (Allaith 2019). Currently, evidence on characteristics of scientific research conducted to determine antioxidant content in ripe date fruits and their research design consistency is still not known. Therefore, the current scoping review was conducted to identify various characteristics of studies that were carried out to determine antioxidant content in ripe date fruits and to make future recommendations to promote higher research design consistency and, thus, improve research quality in this research area.

\section{Methods}

In this scoping review, ripe date fruits are defined as date fruits at full ripeness with a color that was entirely changed from yellow to almost brown or black, and with relatively higher sugar and lower moisture contents. This is equivalent to Tamer stage, the Arabic terms used to describe the full ripening stage of date fruits. Antioxidant content determination research is defined as any original research study with scope related basically to the determination of antioxidant components such as total phenol content and total flavonoid content and related additionally to the determination of antioxidant activity and antioxidant compounds (phenolic compounds and flavonoid compounds) when reported. The framework established by Arksey and O'Malley (2005) was adopted to conduct this scoping review. Furthermore, the current recommendations by Levac et al. (2010) were implemented to enhance the process of searching, screening, and reporting of the scoping review. The applied framework in the present scoping review comprised six stages. These stages include (1) research question identification, (2) relevant study identification, (3) study selection, (4) data charting, (5) result collating, summarizing, and reporting, and (6) experts' consultation (Arksey and O'Malley 2005). Moreover, the Preferred Reporting Items for Systematic Reviews and Meta-Analysis extension for Scoping Reviews (PRISMA-ScR) was used as a guide throughout the review process (Tricco et al. 2018).

\section{Research Question Identification}

The current scoping review was performed to answer five questions. These questions are (1) what are the characteristics of antioxidant content determination research in ripe date fruits, (2) what are the characteristics of collected ripe date fruit samples, (3) what are the characteristics of solvents used to extract antioxidant content, (4) what are the reported information about determining antioxidant content (quantity and quality) and the used analytical methods, citation references for procedures, measurement units, and data presentation methods, and finally, (5) what are the research gaps and future recommendations to promote higher research design consistency and, thus, improve research quality in this research area.

\section{Relevant Study Identification}

A comprehensive search to identify relevant studies was performed using three electronic databases for academic research: Scopus, PubMed, and Web of Science. The search process targeted any relevant study published in March 2019 or any time before. Specific keywords and synonyms related to this review scope were established as search terms. The used search terms include antioxidants, antioxidants content, antioxidant components, antioxidant activity, antioxidant capacity, antioxidant profile, antioxidant composition, phenolic content, total phenols content, phenolic profile, phenolic composition, date fruits, date palm fruits, ripe date fruits, date cultivars, date varieties, and Phoenix dactylifera. The search process was carried out based on the search terms by experienced researchers. During this process, varied combinations of Boolean operators (OR, AND, NOT) including adjacencies and truncations were used to combine the search terms in order to capture potential studies in the academic resources.

\section{Study Selection}

Study selection from potential studies retrieved from academic resources was performed based on previously defined inclusion criteria. The inclusion criteria applied in this scoping review were (1) original research studies that were published in peer-reviewed journals, (2) study language is limited to English, (3) the date fruit samples were collected at full ripeness (Tamer stage), (4) the types of collected ripe date fruit cultivars were specified, (5) the solvent(s) used to extract antioxidant content were specified, and (6) the studies reported determination at least one antioxidant component. 
Study selection was completed in two steps. In the first step, the titles and abstracts of identified studies were screened by researchers independently based on the inclusion criteria. Irrelevant studies were excluded. In the second step, full texts of relevant studies were retrieved and screened by researchers independently to assess their eligibility to be included in the qualitative analysis. Collected data from all researchers were compared after each step to ensure the process steadiness. Any discrepancies between the researchers were discussed and refined. The list of selected studies was finalized and adopted for the next stages in this scoping review.

\section{Data Charting}

Data extracted from the selected studies were collected in the Microsoft Excel spreadsheet. Actually, the extracted data were organized in a charting table that summarized the general characteristics and information reported in the selected studies. The complete charting table was reviewed by all researchers to ensure consistency in the data charting process.

\section{Result Collating, Summarizing, and Reporting}

Data in the charting table were analyzed by using descriptive statistics. The results were summarized in tables and bar graphs that answered the research questions identified in this scoping review. The results were reported to highlight the main findings, address the research gaps, and make useful recommendations for future research. However, the quality of selected studies was not evaluated as it is outside of the current review scope.

\section{Experts' Consultation}

A consultation was conducted with experts and researchers who have a significant research contribution to the area of antioxidant content determination research. The consultation was aimed to ensure the novelty and importance of our findings and usefulness of recommendations for future research.

\section{Results}

\section{Search Process Results}

We identified two hundred and forty records, twenty-eight of which were excluded as duplicates (Fig. 1). Title and abstract screening was conducted for the remaining two hundred and twelve articles, eighty-seven of which were excluded as they did not answer the research questions that were identified in the current scoping review. We retrieved and screened the full texts of the remaining one hundred and twenty-five articles, ninety-three of which were excluded as they were ineligible based on the inclusion criteria. Finally, a sum of thirty-two articles was selected and included in this scoping review (Mansouri et al. 2005; Benmeddour et al. 2013; Ghiaba et al. 2014; Haimoud et al. 2016; Hachani et al. 2018; Allaith 2008; Abbas et al. 2008; Biglari et al. 2008; Shahdadi et al. 2015; Hemmateenejad et al. 2015; Siahpoosh et al. 2016a; Siahpoosh et al. 2016b; Lemine et al. 2014; Bouhlali et al. 2017; Singh et al. 2012; Al Harthi et al. 2015; Haider et al. 2018; Al-Turki et al. 2010; Al-Najada and Mohamed 2014; Hamad et al. 2015; Ali et al. 2016; Farag et al. 2016; Aldhafiri 2017; Saafi et al. 2009; Chaira et al. 2009; Mrabet et al. 2012; El Arem et al. 2012; Kchaou et al. 2013; Kchaou et al. 2014; Mrabet et al. 2015; Hamza et al. 2016; Souli et al. 2018).

\section{Characteristics of the Selected Studies}

The characteristics of the selected studies that were included in this review are presented in Table 1. The selected studies were published in peer-reviewed journals of varied subject categories. Among thirty-two included studies, eighteen studies $(56.3 \%)$ were published in journals related to food science. The remaining sixteen studies $(44.8 \%)$ were published in journals related to subjects other than food science including agricultural sciences $(n=5)$, chemistry $(n=4)$, pharmacology $(n=3)$, nutrition $(n=1)$, and medical sciences $(n=1)$. The selected articles were published starting from 2005 up to 2018. Actually, half of the selected studies $(n=16)$ were published during 2015-2018, while six and ten articles were published during the periods 2005-2009 and 2010-2014, respectively. The highest number of studies $(n=6)$ was published in 2016 (see Fig. 2). However, none of the included studies was published in the years 2006, 2007, or 2011. The institution of the first authors in the selected studies belongs to one of the fourteen countries. First author's institution country was Tunisia in eight articles (25\%). In the same way, it was Algeria, Iran, and Saudi Arabia in different four articles for each country. The selected studies were carried out for diverse purposes. The main objective was to determine antioxidant content in ripe date fruits in fourteen articles (43.8\%). In fact, one study was performed to determine dietary fiber characteristics in ripe date fruits, while another one was done to conduct multivariate statistical analysis. The remaining studies were conducted to determine the effect of specific variables on antioxidant content in date fruits. These variables include ripening stages $(n=6)$, extraction solvents $(n=5)$, geographical locations $(n=2)$, storage periods $(n=1)$, hydrothermal treatments $(n=1)$, and parthenocarpy, the process of producing fruits without seeds $(n=1)$. Funding for conducting research was received from either academic or governmental institutions in about half of the selected studies $(n=17)$, while no fund was reported in the rest of the articles. "No conflict of 
Fig. 1 Flowchart illustrating selection process for the scoping review of antioxidant content determination in ripe date fruits studies

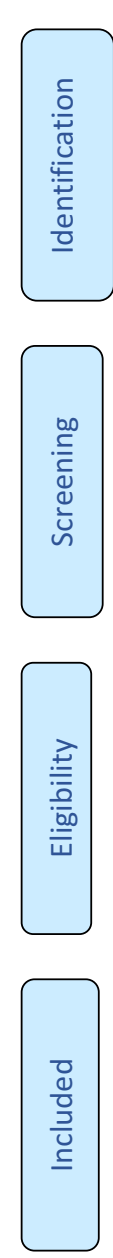

Records identified through database searching $(n=240)$

Scopus $(n=178)$, PubMed $(n=52)$

Web of Science $(n=10)$
Additional records identified

through other sources

$(n=0)$
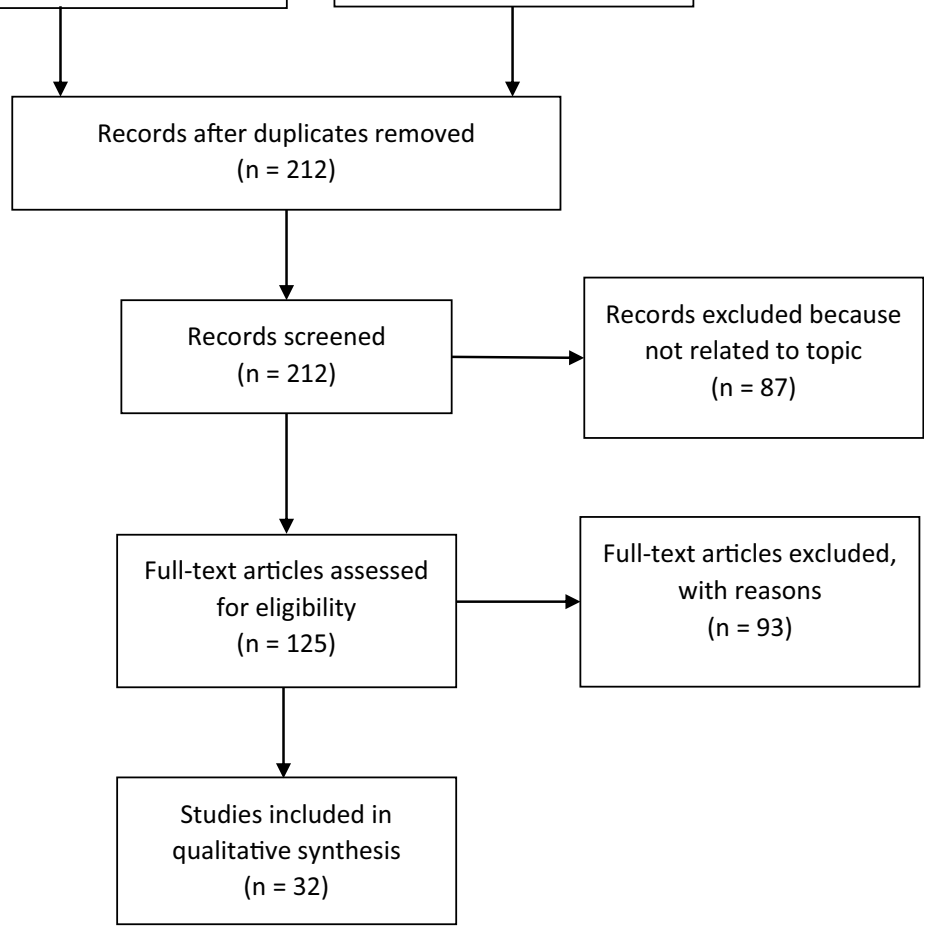

samples. The remaining studies reported that they collect ripe fruits $(n=8)$ or fruits with full ripeness $(n=3)$. The number of collected ripe date fruit cultivars in each selected study ranged from one to eighteen cultivars. Indeed, the number of collected cultivars was one to five, six to ten, and eleven to eighteen in fourteen, thirteen, and five studies, respectively. Figure 3 shows the number of collected cultivars in different studies. The total number of reported ripe date fruit cultivars in all included studies was one hundred and twenty-nine. Most of them $(n=88)$ were reported once in all included studies. However, two cultivars (Deglet Nour and Khalas) were reported twelve times, and one cultivar (Zahedi) was reported six times in all studies. Moreover, the cultivars of Sukari, Kabkab, Medjool, and Allig were reported four times in all studies.

Information about quality, harvest season, local location, source, storage periods, storage temperature, and moisture/dry matter content of collected ripe date fruit samples was reported in thirteen, twenty-two, twenty-nine, fifteen, three, twentyfour, and ten studies, respectively. The collected ripe date fruit samples were mature date fruits with uniform size, and free of physical damage in eleven studies (34.4\%), and second-grade 
Table 1 Characteristics of selected studies that were included in the qualitative analysis in this scoping review $(n=32)$

\begin{tabular}{|c|c|c|}
\hline \multicolumn{2}{|l|}{ Characteristics } & \multirow{2}{*}{$\begin{array}{l}\text { Frequency } \\
\mathrm{N}(\%) \\
18(56.3 \%)\end{array}$} \\
\hline \multirow[t]{6}{*}{ Journal subject categories* } & Food science & \\
\hline & Agricultural sciences & $5(15.6 \%)$ \\
\hline & Chemistry & $4(12.5 \%)$ \\
\hline & Pharmacology & $3(9.4 \%)$ \\
\hline & Nutrition & $1(3.1 \%)$ \\
\hline & Medical sciences & $1(3.1 \%)$ \\
\hline \multirow[t]{3}{*}{ Publication years } & 2005-2009 & $6(18.8 \%)$ \\
\hline & $2010-2014$ & $10(31.3 \%)$ \\
\hline & 2015-2018 & $16(50.0 \%)$ \\
\hline \multirow[t]{14}{*}{ First author's institution country** } & Algeria & $4(12.5 \%)$ \\
\hline & Bahrain & $1(3.1 \%)$ \\
\hline & Egypt & $1(3.1 \%)$ \\
\hline & Greece & $1(3.1 \%)$ \\
\hline & Iran & $4(12.5 \%)$ \\
\hline & Malaysia & $2(6.3 \%)$ \\
\hline & Mauritania & $1(3.1 \%)$ \\
\hline & Morocco & $1(3.1 \%)$ \\
\hline & Oman & $2(6.3 \%)$ \\
\hline & Pakistan & $1(3.1 \%)$ \\
\hline & Saudi Arabia & $4(12.5 \%)$ \\
\hline & Spain & $1(3.1 \%)$ \\
\hline & Tunisia & $8(25.0 \%)$ \\
\hline & USA & $1(3.1 \%)$ \\
\hline \multirow[t]{9}{*}{ Study main objective } & Determine antioxidant content in ripe date fruits & $14(43.8 \%)$ \\
\hline & Determine effect of ripening stages on antioxidant content & $6(18.8 \%)$ \\
\hline & $\begin{array}{l}\text { Determine effect of extraction solvents on antioxidant } \\
\text { content }\end{array}$ & $5(15.6 \%)$ \\
\hline & $\begin{array}{l}\text { Determine effect of geographical locations on antioxidant } \\
\text { content }\end{array}$ & $2(6.3 \%)$ \\
\hline & Determine effect of storage periods on antioxidant content & $1(3.1 \%)$ \\
\hline & $\begin{array}{l}\text { Determine effect of hydrothermal treatments on antioxidant } \\
\text { content }\end{array}$ & $1(3.1 \%)$ \\
\hline & Determine effect of parthenocarpy on antioxidant content & $1(3.1 \%)$ \\
\hline & Determine dietary fiber characteristics in ripe date fruits & $1(3.1 \%)$ \\
\hline & Conduct multivariate statistical analysis & $1(3.1 \%)$ \\
\hline \multirow{3}{*}{$\begin{array}{l}\text { Funding source for conducting } \\
\text { research }\end{array}$} & Academic institution fund & $10(31.3 \%)$ \\
\hline & Governmental institution fund & $7(21.9 \%)$ \\
\hline & No fund is reported & $15(46.9 \%)$ \\
\hline \multirow[t]{2}{*}{ Authors' conflict of interests } & No conflict of interests & $12(37.5 \%)$ \\
\hline & Data are not reported & $20(62.5 \%)$ \\
\hline
\end{tabular}

*The most relevant journal subject category was only reported

**First affiliation was only reported when the first author has more than one affiliation date fruits, with texture defect (relatively hard) in another two studies $(6.3 \%)$. The used ripe date fruit samples were collected during one specific harvest season in twenty studies $(62.5 \%)$ and during two specific harvest seasons in another two studies $(6.3 \%)$. The source of collected ripe date fruit samples was local retail markets, and research stations or private farms in eight and six studies, respectively. In addition, one study had collected the samples from local retail markets or private farms, while another study collected samples from the National Clonal Germplasm Repository for Citrus and Dates (USA) and private farms (Saudi Arabia). The storage periods before analysis of collected ripe date fruit samples were 1 day 
Fig. 2 Bar graph illustrating the number of selected studies that were published each year during the period 2005 to 2018

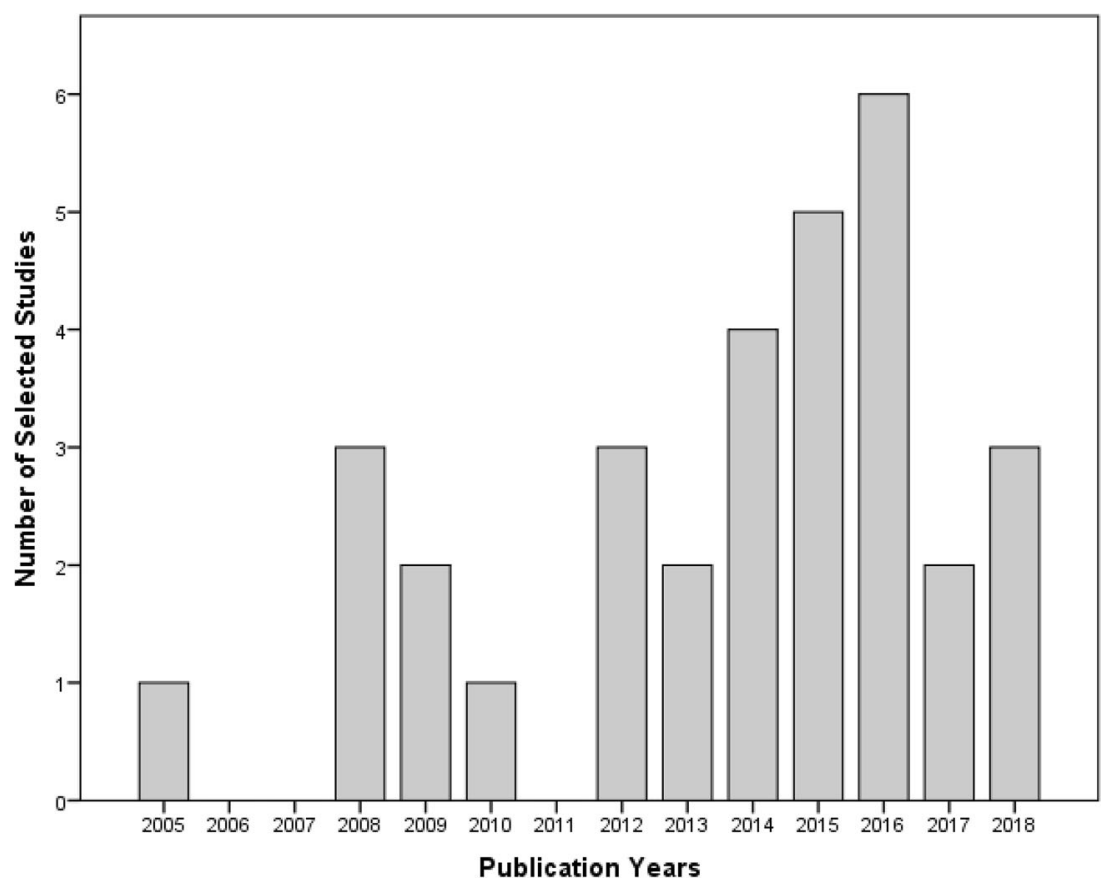

in one study, 1-2 months in another study, and 1 day, 6 months, and 1 year in a third study. The collected samples were stored before analysis at refrigerator temperature $\left(4^{\circ} \mathrm{C}\right)$, and freezer temperature $\left(-20\right.$ to $\left.-18{ }^{\circ} \mathrm{C}\right)$ in ten and thirteen studies, respectively. However, two studies stored the samples at temperature $-40^{\circ} \mathrm{C}$. The moisture content of collected ripe date fruit samples was reported in eight studies, while two studies reported dry matter content.

\section{Characteristics of Extraction Solvents}

The characteristics of extraction solvents that were used to extract antioxidant content from collected ripe date fruit samples are shown in Table 3. The number of solvents used to extract antioxidant content that were reported in each selected study ranged from one to five solvents. Most of the included studies $(n=27)$ used one extraction solvent. Nevertheless, using two, three, and five extraction solvents was reported in one, two, and two different studies, respectively. The total number of extraction solvents that were reported in all included studies was forty-five. Actually, six types of extraction solvents were reported in all studies. Methanolic solvents were the most commonly used solvents to extract antioxidant content and reported in twenty-three articles $(51.1 \%)$. Acetonic solvents, ethanolic solvents, ethyl acetate solvents, aqueous solvents, and methanolic chloroform solvents were reported in eight, seven, three, two, and two studies, respectively. The concentration of used extraction solvents varied in different studies. In fact, methanol with a concentration of $80 \%$ was the most frequently used solvent $(n=12)$ to extract antioxidant content. Absolute methanolic (100\%), methanolic (with a concentration 50\%), and acetonic (with a concentration $70 \%$ ) solvents were reported in four, three, and four studies, respectively. However, the concentration of used solvents was not reported in four studies.

\section{Information About Reported Antioxidant Components, Antioxidant Activity Assays, and Antioxidant Compounds}

Information about reported antioxidant components, antioxidant activity assays, and antioxidant compounds is presented in Table 4. The number of antioxidant components that were reported in each selected study ranged from one to four components. Although there was one antioxidant component reported in fifteen studies, there were two, three, and four antioxidant components reported in eight, six, and three studies, respectively. In fact, six types of antioxidant components were reported in all selected studies. Total phenol content was reported in all studies $(n=32)$. However, total flavonoid content, total condensed tannins/total tannin content, total flavonol content, and oligomeric proanthocyanidin content were reported in seventeen, six, three, and two studies, respectively. Finally, total carotenoid content was reported in one article.

The number of antioxidant activity assays that were reported in each selected study ranged from one to six assays. While one antioxidant activity assay was reported in nine studies, six antioxidant activity assays were reported in one study. Actually, twelve types of antioxidant activity assays were reported in all selected studies. DPPH radical scavenging capacity assay 
Table 2 Characteristics of collected ripe date fruit samples reported in selected studies that were included in the qualitative analysis in this scoping review $(n=32)$

\begin{tabular}{|c|c|c|}
\hline \multicolumn{2}{|l|}{ Characteristics } & $\begin{array}{l}\text { Frequency } \\
\mathrm{N}(\%) \\
5(15.6 \%)\end{array}$ \\
\hline $\begin{array}{l}\text { Production country for collected ripe date fruit } \\
\text { samples* }\end{array}$ & $\begin{array}{l}\text { Algeria } \\
\text { Iran } \\
\text { Mauritania } \\
\text { Morocco } \\
\text { Oman } \\
\text { Pakistan } \\
\text { Saudi Arabia } \\
\text { Tunisia } \\
\text { Bahrain/Saudi Arabia/Tunisia } \\
\text { Saudi Arabia/USA }\end{array}$ & $\begin{array}{l}5(15.6 \%) \\
6(18.8 \%) \\
1(3.1 \%) \\
1(3.1 \%) \\
2(6.3 \%) \\
1(3.1 \%) \\
5(15.6 \%) \\
9(28.1 \%) \\
1(3.1 \%) \\
1(3.1 \%)\end{array}$ \\
\hline $\begin{array}{l}\text { Ripening stage description for collected ripe } \\
\text { date fruit samples }\end{array}$ & $\begin{array}{l}\text { Tamer stage } \\
\text { Ripe fruits } \\
\text { Full ripeness }\end{array}$ & $\begin{array}{l}21(65.6 \%) \\
8(25.0 \%) \\
3(9.4 \%)\end{array}$ \\
\hline $\begin{array}{l}\text { Number of collected ripe date fruit cultivars in } \\
\text { each selected study }\end{array}$ & $\begin{array}{l}1-5 \\
6-10 \\
11-18\end{array}$ & $\begin{array}{l}14(43.8 \%) \\
13(40.6 \%) \\
5(15.6 \%)\end{array}$ \\
\hline $\begin{array}{l}\text { Frequency of reporting each ripe date fruit } \\
\text { cultivar in all selected studies** }\end{array}$ & $\begin{array}{l}12 \\
6 \\
4 \\
3 \\
2 \\
1\end{array}$ & $\begin{array}{l}2(1.6 \%) \\
1(0.8 \%) \\
4(3.1 \%) \\
11(8.5 \%) \\
23(17.8 \%) \\
88(68.2 \%)\end{array}$ \\
\hline $\begin{array}{l}\text { Information about quality of collected ripe date } \\
\text { fruit samples }\end{array}$ & $\begin{array}{l}\text { Mature date fruits with uniform size, and free of } \\
\text { physical damage } \\
\text { Second-grade date fruits, with texture defect } \\
\text { (relatively hard) } \\
\text { Data are not reported }\end{array}$ & $\begin{array}{l}11(34.4 \%) \\
2(6.3 \%) \\
19(59.4 \%)\end{array}$ \\
\hline $\begin{array}{l}\text { Information about harvest season of collected } \\
\text { ripe date fruit samples }\end{array}$ & $\begin{array}{l}\text { One specific harvest season is reported } \\
\text { Two specific harvest seasons are reported } \\
\text { Data are not reported }\end{array}$ & $\begin{array}{l}20(62.5 \%) \\
2(6.3 \%) \\
10(31.3 \%)\end{array}$ \\
\hline $\begin{array}{l}\text { Information about local location of collected } \\
\text { ripe date fruit samples }\end{array}$ & $\begin{array}{l}\text { Local geographical location is reported } \\
\text { Data are not reported }\end{array}$ & $\begin{array}{l}29(90.6 \%) \\
3(9.4 \%)\end{array}$ \\
\hline $\begin{array}{l}\text { Information about source of collected ripe date } \\
\text { fruit samples }\end{array}$ & $\begin{array}{l}\text { Local retail markets } \\
\text { Research stations or private farms } \\
\text { Local retail markets or private farms } \\
\text { National Clonal Germplasm Repository for Citrus } \\
\text { and Dates (USA)/private farms (Saudi Arabia) } \\
\text { Data are not reported }\end{array}$ & $\begin{array}{l}8(25.0 \%) \\
6(18.8 \%) \\
1(3.1 \%) \\
1(3.1 \%)\end{array}$ \\
\hline $\begin{array}{l}\text { Information about storage periods before } \\
\text { analysis of collected ripe date fruit samples }\end{array}$ & $\begin{array}{l}1 \text { day } \\
1-2 \text { months } \\
1 \text { day, } 6 \text { months, and } 12 \text { months } \\
\text { Data are not reported }\end{array}$ & $\begin{array}{l}1(3.1 \%) \\
1(3.1 \%) \\
1(3.1 \%) \\
29(90.6 \%)\end{array}$ \\
\hline $\begin{array}{l}\text { Information about storage temperature before } \\
\text { analysis of collected ripe date fruit samples }\end{array}$ & $\begin{array}{l}\text { Refrigerator temperature }\left(4^{\circ} \mathrm{C}\right) \\
\text { Freezer temperature }\left(-20 \text { to }-18{ }^{\circ} \mathrm{C}\right) \\
-40{ }^{\circ} \mathrm{C} \\
\text { Data are not reported }\end{array}$ & $\begin{array}{l}10(31.3 \%) \\
13(40.6 \%) \\
2(6.3 \%) \\
7(21.9 \%)\end{array}$ \\
\hline $\begin{array}{l}\text { Information about moisture/dry matter content } \\
\text { of collected ripe date fruit samples }\end{array}$ & $\begin{array}{l}\text { Moisture content is reported } \\
\text { Dry matter content is reported } \\
\text { Data are not reported }\end{array}$ & $\begin{array}{l}8(25.0 \%) \\
2(6.3 \%) \\
22(68.8 \%)\end{array}$ \\
\hline
\end{tabular}

*Studies that reported ripe date fruit samples of more than one origin country are reported separately

**Total number of reported ripe date fruit cultivars in all selected studies is 129
(DPPH assay), ferric reducing antioxidant power assay (FRAP assay), ABTS radical scavenging capacity assay (ABTS assay), ferrous ion chelating assay (metal chelating assay), and total antioxidant capacity assay (phosphomolybdenum assay) were reported in twenty-seven, eighteen, eleven, six, and five studies, respectively. Three studies were reported each of the following assays: hydrogen peroxide scavenging assay (hydrogen peroxide assay), superoxide anion scavenging assay (superoxide anion assay), and cupric ion reducing antioxidant capacity assay (CUPRAC assay). Similarly, two studies were reported each of the following assays: $\beta$-carotene-linoleic acid bleaching assay ( $\beta$-carotene bleaching assay), hydroxyl radical scavenging assay (hydroxyl radical assay), and lipoperoxyl radical scavenging assay (lipoperoxyl radical assay). Finally, one study reported ascorbic acid equivalent antioxidant capacity assay (AEAC assay). The range information for total phenols and total flavonoids 
Fig. 3 Bar graph illustrating the number of selected studies that reported each number of collected date fruit cultivars (1-18)

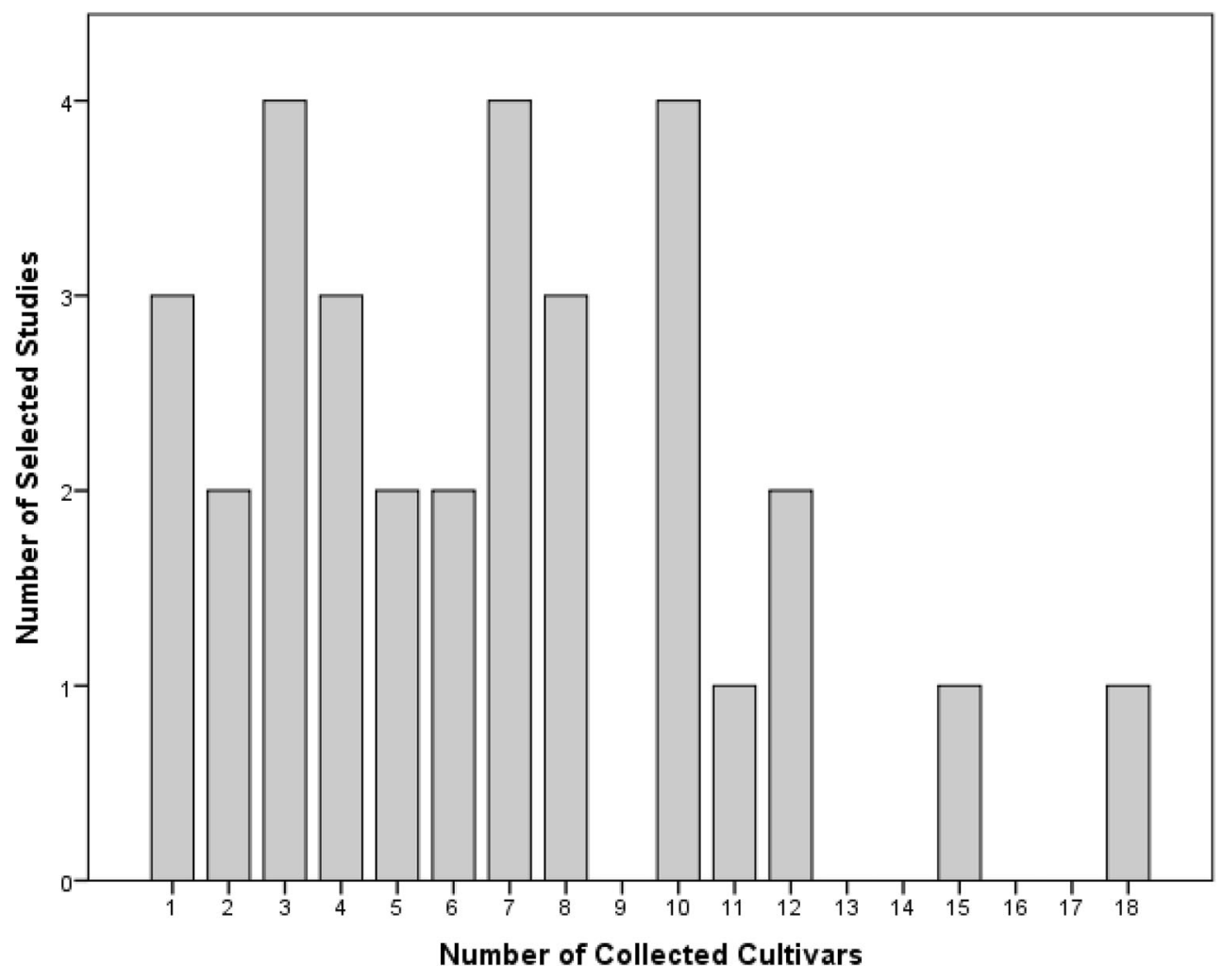

and antioxidant activity (DPPH and FRAP assays) that were reported in selected studies, as well as the name of ripe date fruit cultivars with minimum and maximum values, is presented in Table 5 .

A total of twenty different phenolic compounds were reported in seven studies. The number of phenolic compounds that were reported in each included study ranged from three to sixteen compounds. Gallic acid and p-coumaric acid were reported in all seven studies, while caffeic acid was reported in six of them. Likewise, a total of fifteen different flavonoid compounds were reported in four studies. The number of flavonoid compounds reported in each included study was either five or thirteen compounds. Rutin, quercetin, and luteolin were reported in all four studies, while isoquercetrin and apigenin were reported in three of them.

\section{Information About Reported Analytical Methods Used to Determine Antioxidant Components}

Information about reported analytical methods that were used to determine antioxidant components is shown in Table 6 . Generally, antioxidant component determination in all selected studies was carried out by using colorimetric methods. Contrarily, high-performance liquid chromatography (HPLC) was used in a limited number of studies to determine antioxidant components. Colorimetric method using folinciocalteu reagent was used to determine total phenol content in twenty-nine studies, while it was determined by using
HPLC in the remaining three studies. In the same way, colorimetric method using aluminum chloride reagent was used to determine total flavonoid content in fifteen studies, while it was determined by using HPLC in two studies. Total condensed tannins/total tannin content was determined by colorimetric methods, but different reagents were used, which include vanillin reagent $(n=4)$, folin-ciocalteu reagent $(n=1)$, and ferric reagent $(n=1)$. Finally, colorimetric methods were used to determine total flavonols, oligomeric proanthocyanidin, and total carotenoids by using aluminum chloride reagent $(n=3)$, ammonium ferric sulfate dodecahydrate reagent $(n=2)$, and butylated hydroxytoluene reagent $(n=1)$, respectively.

\section{References Used to Cite Procedures Related to Solvent Extraction, Antioxidant Component Determination, and Antioxidant Activity Assays}

The references that were used to cite procedures that were related to solvent extraction, antioxidant component determination, and antioxidant activity assays are presented in Table 7. Many selected studies did not use any references to cite procedures that were related to solvent extraction, antioxidant component determination, and antioxidant activity assays that were applied on collected ripe date fruit samples. However, a wide range of references were used to cite these procedures in the remaining studies. Although there were no references used to cite solvent extraction procedures in about 
Table 3 Characteristics of solvents used to extract antioxidant content from collected ripe date fruit samples in selected studies that were included in the qualitative analysis in this scoping review $(n=32)$

\begin{tabular}{|c|c|c|}
\hline \multicolumn{2}{|l|}{ Characteristics } & \multirow{2}{*}{$\begin{array}{l}\text { Frequency } \\
\mathrm{N}(\%) \\
27(84.4 \%)\end{array}$} \\
\hline Number of solvents used to extract antioxidant content reported in & 1 & \\
\hline & 2 & $1(3.1 \%)$ \\
\hline & 3 & $2(6.3 \%)$ \\
\hline & 5 & $2(6.3 \%)$ \\
\hline \multirow[t]{6}{*}{ Type of extraction solvents reported in all selected studies* } & Methanolic solvents & $23(51.1 \%)$ \\
\hline & Acetonic solvents & $8(17.8 \%)$ \\
\hline & Ethanolic solvents & $7(15.6 \%)$ \\
\hline & Ethyl acetate solvents & $3(6.7 \%)$ \\
\hline & Aqueous solvents & $2(4.4 \%)$ \\
\hline & $\begin{array}{l}\text { Methanolic chloroform } \\
\text { solvents }\end{array}$ & $2(4.4 \%)$ \\
\hline \multirow[t]{6}{*}{ Concentrations of used methanolic solvents* } & $100 \%$ & $4(8.9 \%)$ \\
\hline & $95 \%$ & $1(2.2 \%)$ \\
\hline & $88 \%$ & $1(2.2 \%)$ \\
\hline & $80 \%$ & $12(26.7 \%)$ \\
\hline & $50 \%$ & $3(6.7 \%)$ \\
\hline & Data are not reported & $2(4.4 \%)$ \\
\hline \multirow[t]{4}{*}{ Concentrations of used acetonic solvents* } & $100 \%$ & $1(2.2 \%)$ \\
\hline & $80 \%$ & $2(4.4 \%)$ \\
\hline & $70 \%$ & $4(8.9 \%)$ \\
\hline & $60 \%$ & $1(2.2 \%)$ \\
\hline \multirow[t]{4}{*}{ Concentrations of used ethanolic solvents* } & $100 \%$ & $2(4.4 \%)$ \\
\hline & $80 \%$ & $2(4.4 \%)$ \\
\hline & $50 \%$ & $2(4.4 \%)$ \\
\hline & $20 \%$ & $1(2.2 \%)$ \\
\hline \multirow[t]{2}{*}{ Concentrations of used ethyl acetate solvents* } & $100 \%$ & $2(4.4 \%)$ \\
\hline & $50 \%$ & $1(2.2 \%)$ \\
\hline Concentrations of used aqueous solvents* & $100 \%$ & $2(4.4 \%)$ \\
\hline Concentrations of used methanolic chloroform solvents* & Data are not reported & $2(4.4 \%)$ \\
\hline
\end{tabular}

*Total number of extraction solvents that were reported in all selected studies is 45 half of the included studies $(n=17)$, two primary references (Biglari et al. 2008; and Al-Farsi et al. 2005) were cited in nine studies. Two references (Singleton and Rossi 1965; and AlFarsi et al. 2005) were cited mainly in fifteen studies for total phenol determination procedures. Likewise, two references (Kim et al. 2003; and Zhishen et al. 1999) were cited mainly in ten studies for total flavonoid determination procedures. One reference (Julkunen-Tiitto 1985) was cited mainly in two studies for total condensed tannins/total tannin determination procedures. Moreover, a single reference was used to cite the procedures used to determine total flavonols (Jimoh et al. 2010), oligomeric proanthocyanidin (Quettier-Deleu et al. 2000), and total carotenoids (Al-Farsi et al. 2005).

While some antioxidant activity assays were cited mainly by a specific reference, other antioxidant activity assays were cited by several references in different studies. A specific reference was used mostly to cite procedures for DPPH assay
(Brand-Williams et al. 1995), FRAP assay (Benzie and Strain 1996), ABTS assay (Re et al. 1999), and phosphomolybdenum assay (Prieto et al. 1999). On the other hand, different references were used to cite the procedures for the remaining antioxidant activity assays (metal chelating assay, hydrogen peroxide assay, superoxide anion assay, CUPRAC assay, $\beta$-carotene bleaching assay, hydroxyl radical assay, lipoperoxyl radical assay, and AEAC assay) in different studies.

\section{Measurement Units Used to Quantify Values of Antioxidant Components, Antioxidant Activity, and Antioxidant Compounds}

The measurement units that were used to quantify values of antioxidant components, antioxidant activity, and antioxidant compounds are provided in Table 8 . Various selected studies 
Table 4 Information reported about numbers and types of antioxidant components, antioxidant activity assays, and antioxidant compounds (phenolic compounds and flavonoid compounds) determined for collected ripe date fruit samples in selected studies included in the qualitative analysis in this scoping review $(n=32)$

\begin{tabular}{|c|c|c|}
\hline \multicolumn{2}{|l|}{ Information about } & \multirow{2}{*}{$\begin{array}{l}\text { Frequency N (\%) } \\
15(46.9 \%)\end{array}$} \\
\hline Number of antioxidant components reported in & 1 & \\
\hline each selected study & 2 & $8(25.0 \%)$ \\
\hline & 3 & $6(18.8 \%)$ \\
\hline & 4 & $3(9.4 \%)$ \\
\hline \multirow{6}{*}{$\begin{array}{l}\text { Types of antioxidant components reported in all } \\
\text { selected studies }\end{array}$} & Total phenols & $32(100.0 \%)$ \\
\hline & Total flavonoids & $17(53.1 \%)$ \\
\hline & Total condensed tannins/total tannins & $6(18.8 \%)$ \\
\hline & Total flavonols & $3(9.4 \%)$ \\
\hline & Oligomeric proanthocyanidin & $2(6.3 \%)$ \\
\hline & Total carotenoids & $1(3.1 \%)$ \\
\hline \multirow{6}{*}{$\begin{array}{l}\text { Number of antioxidant activity assays reported in } \\
\text { each selected study }\end{array}$} & 1 & $9(28.1 \%)$ \\
\hline & 2 & $9(28.1 \%)$ \\
\hline & 3 & $5(15.6 \%)$ \\
\hline & 4 & $5(15.6 \%)$ \\
\hline & 5 & $3(9.4 \%)$ \\
\hline & 6 & $1(3.1 \%)$ \\
\hline \multirow{12}{*}{$\begin{array}{l}\text { Types of antioxidant activity assays reported in } \\
\text { all selected studies }\end{array}$} & DPPH radical scavenging capacity assay (DPPH assay) & $27(84.4 \%)$ \\
\hline & Ferric reducing antioxidant power assay (FRAP assay) & $18(56.3 \%)$ \\
\hline & ABTS radical scavenging capacity assay (ABTS assay) & $11(34.4 \%)$ \\
\hline & Ferrous ion chelating assay (metal chelating assay) & $6(18.8 \%)$ \\
\hline & Total antioxidant capacity assay (phosphomolybdenum assay) & $5(15.6 \%)$ \\
\hline & Hydrogen peroxide scavenging assay (hydrogen peroxide assay) & $3(9.4 \%)$ \\
\hline & Superoxide anion scavenging assay (superoxide anion assay) & $3(9.4 \%)$ \\
\hline & Cupric ion reducing antioxidant capacity assay (CUPRAC assay) & $3(9.4 \%)$ \\
\hline & $\beta$-carotene-linoleic acid bleaching assay ( $\beta$-carotene bleaching assay) & $2(6.3 \%)$ \\
\hline & Hydroxyl radical scavenging assay (hydroxyl radical assay) & $2(6.3 \%)$ \\
\hline & Lipoperoxyl radical scavenging assay (lipoperoxyl radical assay) & $2(6.3 \%)$ \\
\hline & Ascorbic acid equivalent antioxidant capacity assay (AEAC assay) & $1(3.1 \%)$ \\
\hline \multirow{8}{*}{$\begin{array}{l}\text { Number of phenolic compounds reported in each } \\
\text { selected study }\end{array}$} & 3 & $1(3.1 \%)$ \\
\hline & 4 & $1(3.1 \%)$ \\
\hline & 5 & $1(3.1 \%)$ \\
\hline & 6 & $1(3.1 \%)$ \\
\hline & 9 & $1(3.1 \%)$ \\
\hline & 11 & $1(3.1 \%)$ \\
\hline & 16 & $1(3.1 \%)$ \\
\hline & Data are not reported & $25(78.1 \%)$ \\
\hline \multirow{6}{*}{$\begin{array}{l}\text { Types of phenolic compounds reported in all } \\
\text { selected studies }\end{array}$} & Gallic acid, p-coumaric acid & $7(21.9 \%)$ \\
\hline & Caffeic acid & $6(18.8 \%)$ \\
\hline & Ferulic acid, syringic acid & $5(15.6 \%)$ \\
\hline & Protocatechuic acid, catechin, chlorogenic acid & $3(9.4 \%)$ \\
\hline & Vanillic acid, o-coumaric acid, cinnamic acid & $2(6.3 \%)$ \\
\hline & $\begin{array}{l}\text { Epicatechin, resorcinol, ellagic acid, 3-hydroxybenzoic acid, apigenic acid, } \\
\text { isovanillic acid, m-coumaric acid, phenylacetic acid, hydroxyphenylacetic acid }\end{array}$ & $1(3.1 \%)$ \\
\hline \multirow{3}{*}{$\begin{array}{l}\text { Number of flavonoid compounds reported in } \\
\text { each selected study }\end{array}$} & 5 & $3(9.4 \%)$ \\
\hline & 13 & $1(3.1 \%)$ \\
\hline & Data are not reported & $28(87.5 \%)$ \\
\hline \multirow{3}{*}{$\begin{array}{l}\text { Types of flavonoid compounds reported in all } \\
\text { selected studies }\end{array}$} & Rutin, quercetin, luteolin & $4(12.5 \%)$ \\
\hline & Isoquercetrin, apigenin & $3(9.4 \%)$ \\
\hline & $\begin{array}{l}\text { Quercetrin, apergenin-7-o-glucoside, naringenin, naringin, cirsiliol } \\
\text { hyperoside, luteolin-7-glucoside, silymarin, crisilineol, acacetin }\end{array}$ & $1(3.1 \%)$ \\
\hline
\end{tabular}

used several types of measurement units to quantify the values of antioxidant components, antioxidant activity assays, and antioxidant compounds (phenolic compounds and flavonoid compounds) that were determined for collected ripe date fruit samples. Total phenol content values were reported by using nine different measurement units in all studies $(n=32)$. However, most of these studies $(n=22)$ used one of the two measurement units: $\mathrm{mg}$ gallic acid equivalents (GAE)/100 g fresh weight (FW) or mg GAE/100 g dry weight (DW). Values of total flavonoid content, total condensed tannins/ total tannin content, and total flavonol content were reported by using eight, four, and two different measurement units in different studies that reported these antioxidant components, respectively. Actually, four studies used $\mathrm{mg}$ catechin equivalents $(\mathrm{CE}) / 100 \mathrm{~g} \mathrm{DW}$, and three studies used mg quercetin equivalents $(\mathrm{QE}) / 100 \mathrm{~g}$ DW as measurement units to quantify 


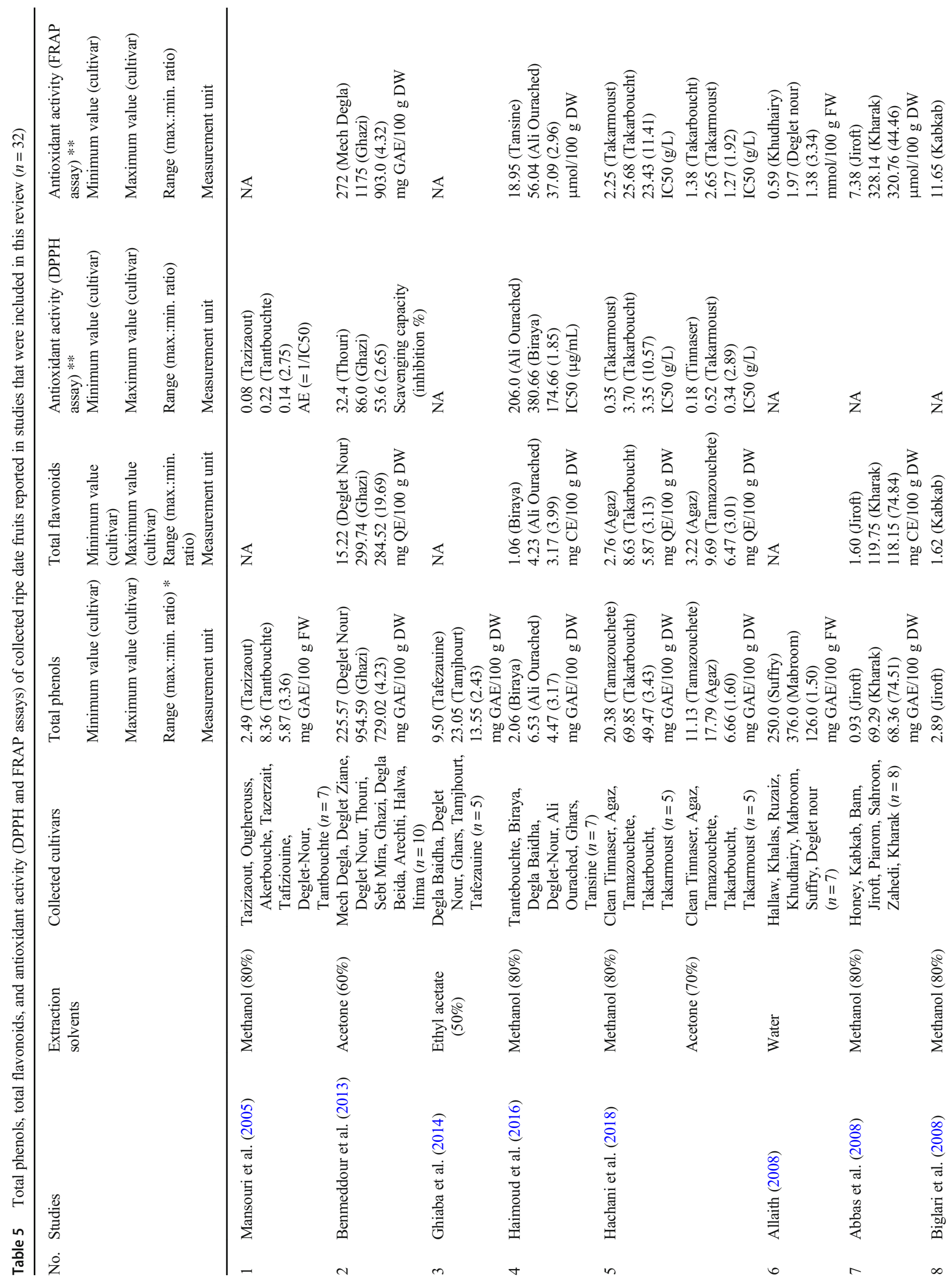




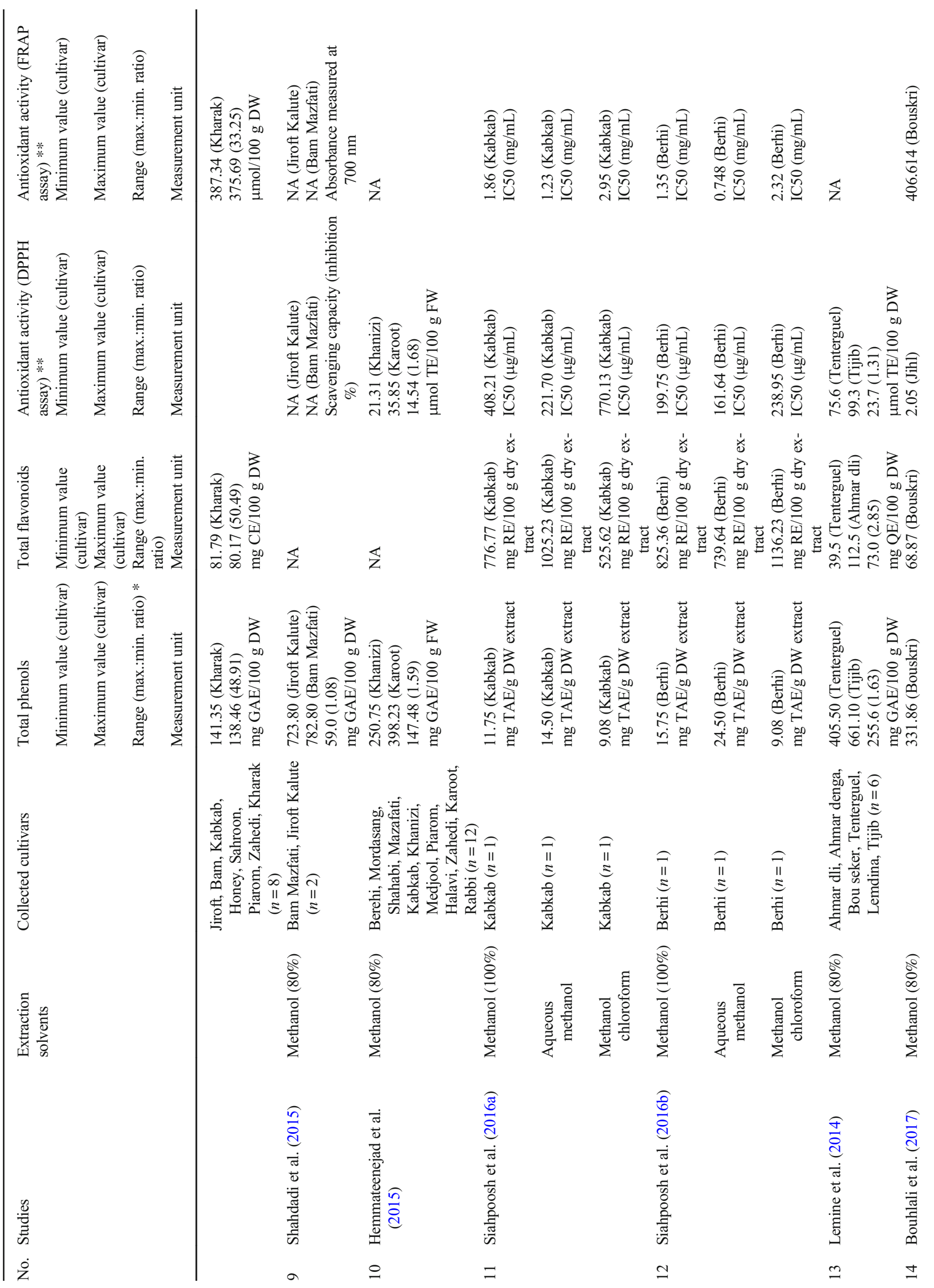




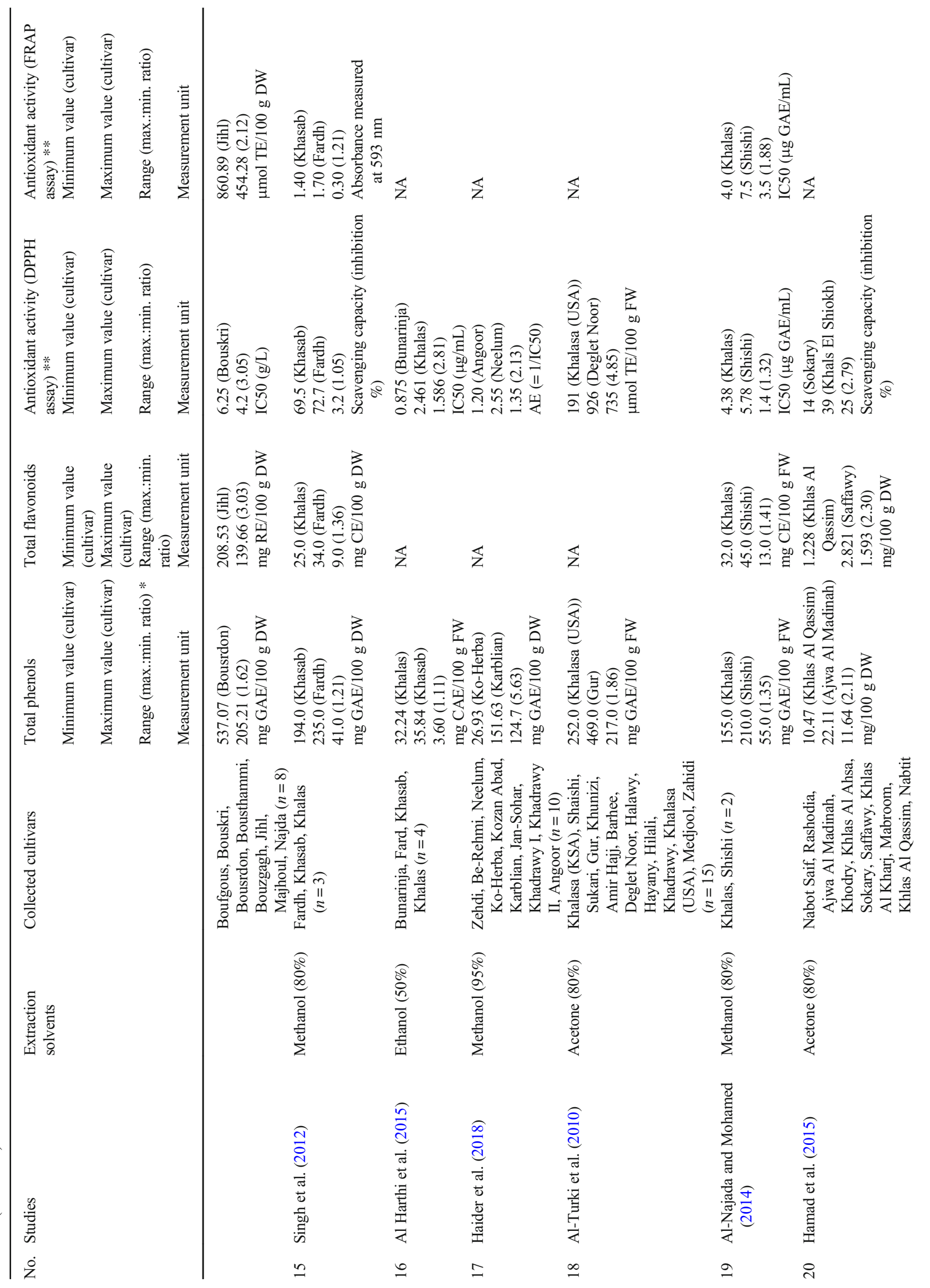




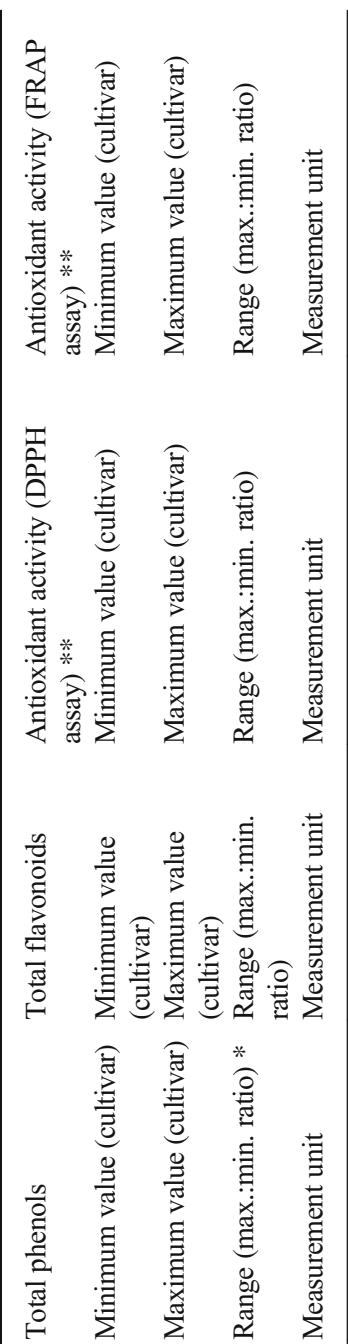

尊

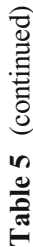

$\begin{array}{llllll}\frac{1}{z} & \mathbb{z} & \mathbb{z} & \mathbb{z} & \mathbb{z} & \mathbb{z}\end{array}$

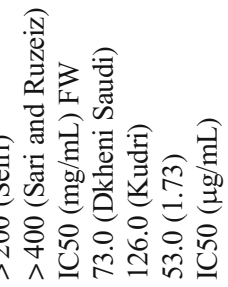

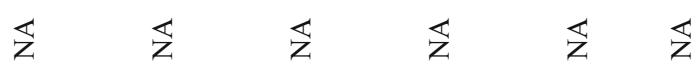

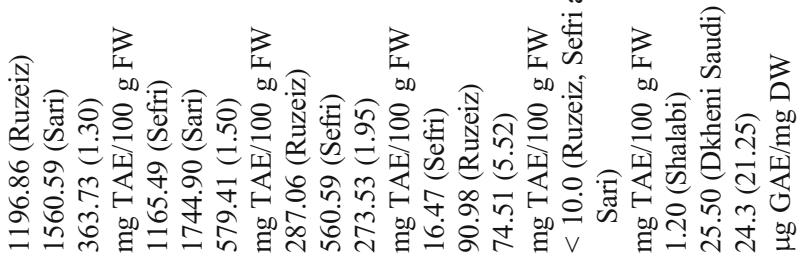

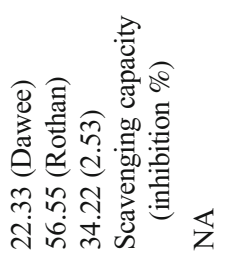

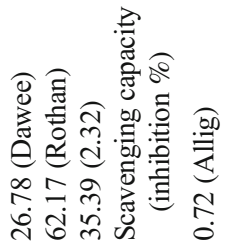

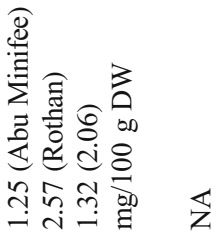

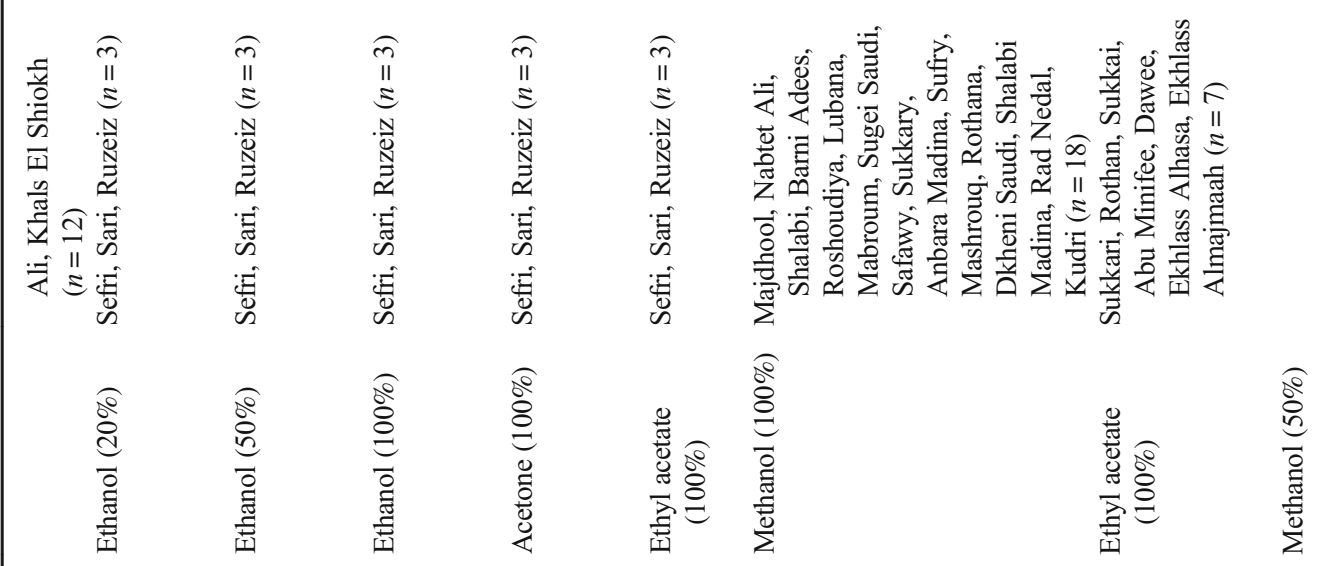

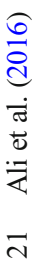

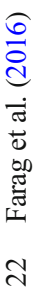

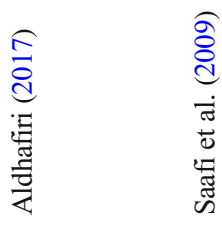

กิ

㫕 


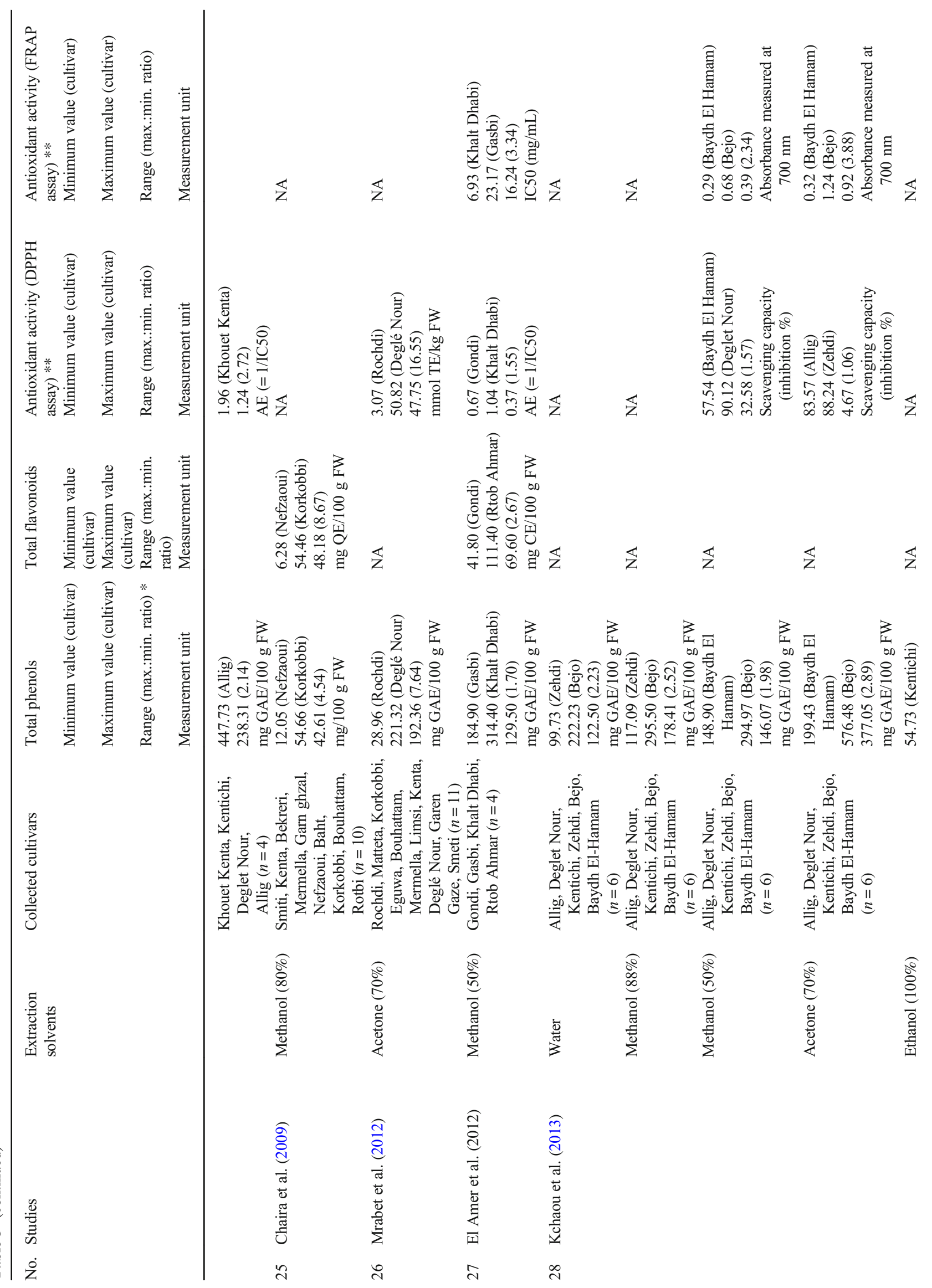




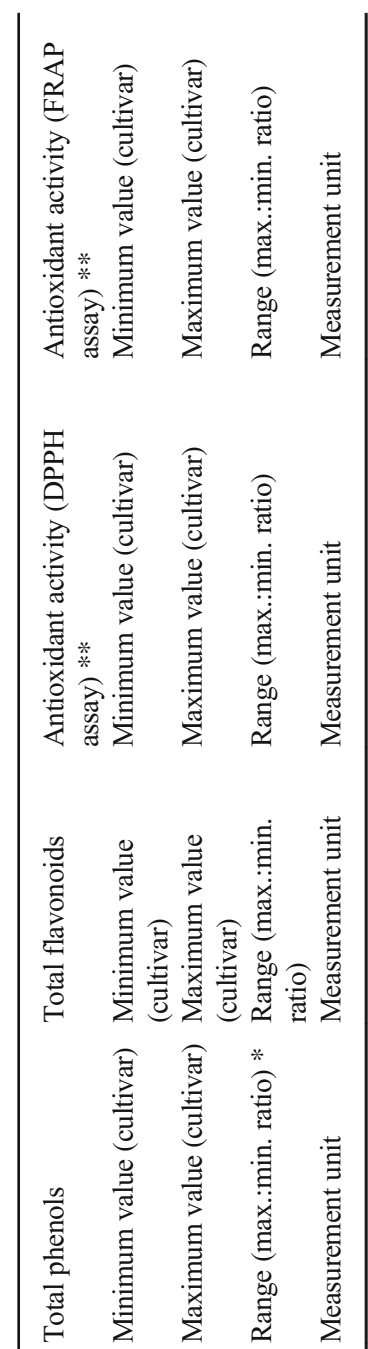

竞

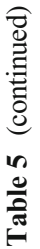

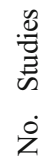

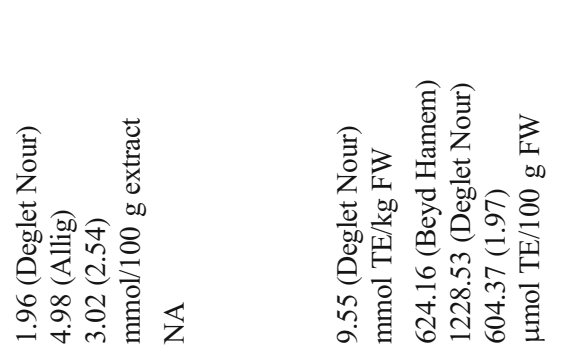

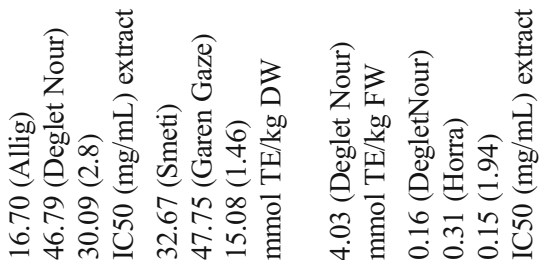
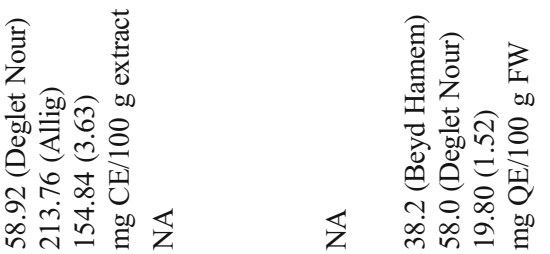

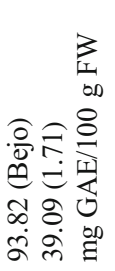

言 苛

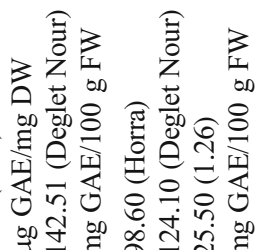

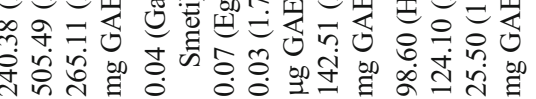

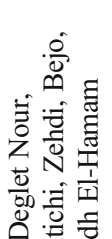

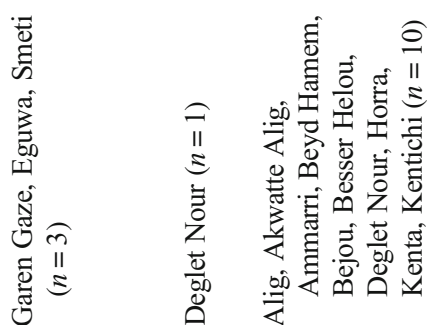

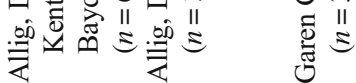
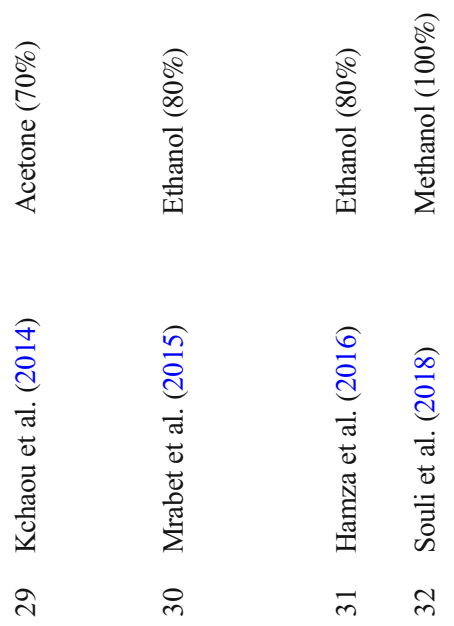

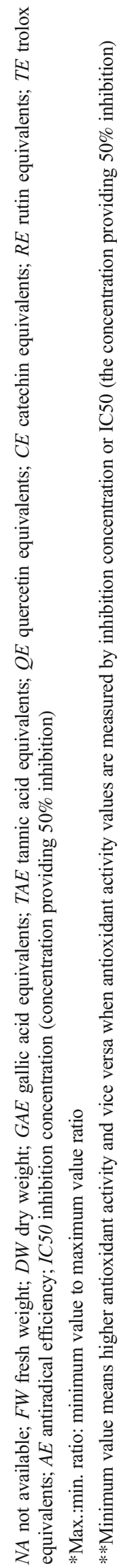


Table 6 Information reported about analytical methods used to determine antioxidant components for collected ripe date fruit samples in selected studies that were included in the qualitative analysis in this scoping review $(n=32)$

\begin{tabular}{|c|c|c|}
\hline $\begin{array}{l}\text { Information about analytical methods } \\
\text { used to determine }\end{array}$ & & $\begin{array}{l}\text { Frequency } \\
\mathrm{N}(\%)\end{array}$ \\
\hline \multirow[t]{2}{*}{ Total phenols } & Colorimetric method using folin-ciocalteu reagent & $29(90.6 \%)$ \\
\hline & HPLC & $3(9.4 \%)$ \\
\hline \multirow[t]{2}{*}{ Total flavonoids } & $\begin{array}{l}\text { Colorimetric method using aluminum chloride } \\
\text { reagent }\end{array}$ & $15(46.9 \%)$ \\
\hline & HPLC & $2(6.3 \%)$ \\
\hline \multirow[t]{3}{*}{ Total condensed tannins/total tannins } & Colorimetric method using vanillin reagent & $4(12.5 \%)$ \\
\hline & Colorimetric method using folin-ciocalteu reagent & $1(3.1 \%)$ \\
\hline & Colorimetric method using ferric reagent & $1(3.1 \%)$ \\
\hline Total flavonols & $\begin{array}{l}\text { Colorimetric method using aluminum chloride } \\
\text { reagent }\end{array}$ & $3(9.4 \%)$ \\
\hline Oligomeric proanthocyanidin & $\begin{array}{l}\text { Colorimetric method using ammonium ferric } \\
\text { sulfate dodecahydrate reagent }\end{array}$ & $2(6.3 \%)$ \\
\hline Total carotenoids & $\begin{array}{l}\text { Colorimetric method using butylated } \\
\text { hydroxytoluene reagent }\end{array}$ & $1(3.1 \%)$ \\
\hline
\end{tabular}

total flavonoid content values. Four studies used either mg $\mathrm{CE} / 100 \mathrm{~g} \mathrm{FW}$ or $\mathrm{mg} \mathrm{CE} / 100 \mathrm{~g} \mathrm{DW}$ as measurement units to quantify total condensed tannins/total tannin content values. Furthermore, total flavonol content values were reported by using one of the two measurement units: mg rutin equivalents (RE)/100 g FW or mg RE/100 g DW. Values of oligomeric proanthocyanidin content and total carotenoid content were quantified by using $\mathrm{mg}$ of cyanidin equivalents (CYE)/ $100 \mathrm{mg}$ dry extract and $\mathrm{mg} / 100 \mathrm{~g} \mathrm{FW}$ as measurement units, respectively.

Higher variability was observed in measurement units used to quantify the values of antioxidant activity assays. Values of DPPH assay, FRAP assay values, ABTS assay, and metal chelating assay were reported by using eleven, thirteen, five, and four different measurement units in different studies that reported these assays, respectively. DPPH assay values were essentially reported in different studies by using three measurement units: scavenging capacity (inhibition \%), inhibition concentration (IC50) $(\mu \mathrm{g} / \mathrm{mL})$, or antiradical efficiency (AE). FRAP assay values were mainly reported in different studies by using two measurement units: IC50 (mg/mL) or $\mu \mathrm{mol} /$ $100 \mathrm{~g} \mathrm{DW}$. ABTS assay values were mostly reported in different studies by using two measurement units: $\mu$ mol trolox equivalents (TE)/100 g FW or $\mu \mathrm{mol} \mathrm{TE} / 100 \mathrm{~g} \mathrm{DW}$. In the same way, metal chelating assay values were mainly reported in different studies by using two measurement units: chelating activity (inhibition \%) or IC50 $(\mu \mathrm{g} / \mathrm{mL})$. However, phosphomolybdenum assay values were reported in five different studies by using five measurement units. Values of the remaining antioxidant activity assays (hydrogen peroxide assay, superoxide anion assay, CUPRAC assay, $\beta$-carotene bleaching assay, hydroxyl radical assay, lipoperoxyl radical assay, and AEAC assay) were quantified by using three different measurement units or less. Finally, two different measurement units (mg/100 g FW or mg/100 g DW) were used to report the values of antioxidant compounds (phenolic compounds and flavonoid compounds).

\section{Data Presentation Methods Used to Report Values of Moisture/Dry Matter Content, Antioxidant Components, Antioxidant Activity Assays, and Antioxidant Compounds}

Data presentation methods that were used to report values of moisture/dry matter content, antioxidant components, antioxidant activity assays, and antioxidant compounds are presented in Table 9. Two data presentation methods (tables and bar graphs) were used to report the values of moisture/dry matter content, antioxidant components, and antioxidant activity assays in different studies. Contrarily, values of antioxidant compounds (phenolic compounds and flavonoid compounds) were reported by using tables. Values of moisture/dry matter content, antioxidant components, and antioxidant activity assays were reported by using tables in seven, twenty-six, and twenty-four studies, respectively, and bar graphs in three, six, and eight studies, respectively.

\section{Discussion}

This scoping review is the first attempt that was carried out to map the available evidence from studies conducted to determine antioxidant content in ripe date fruits. We called to this work by huge inconsistency, and high variability in research design in studies that investigated this research area. This work will enable researchers in the field to identify the gaps and drawbacks in the current literature and the relevant practices and appropriate research designs in future studies. 
Table 7 Citation references for procedures related to solvent extraction, antioxidant component determination, and antioxidant activity assays applied on collected ripe date fruit samples in selected studies that were included in the qualitative analysis in this scoping review $(n=32)$

\begin{tabular}{|c|c|c|}
\hline Citation references for procedures related to & & Frequency $\mathrm{N}(\%)$ \\
\hline \multirow[t]{4}{*}{ Solvent extraction } & Biglari et al. (2008) & $5(15.6 \%)$ \\
\hline & Al-Farsi et al. (2005) & $4(12.5 \%)$ \\
\hline & Others & $6(18.8 \%)$ \\
\hline & No citation & $17(53.1 \%)$ \\
\hline \multirow[t]{4}{*}{ Total phenol determination } & Singleton and Rossi (1965) & $9(28.1 \%)$ \\
\hline & Al-Farsi et al. (2005) & $6(18.8 \%)$ \\
\hline & Others & $11(34.4 \%)$ \\
\hline & No citation & $6(18.8 \%)$ \\
\hline \multirow[t]{4}{*}{ Total flavonoid determination } & Kim et al. (2003) & $7(21.9 \%)$ \\
\hline & Zhishen et al. (1999) & $3(9.4 \%)$ \\
\hline & Others & $6(18.8 \%)$ \\
\hline & No citation & $1(3.1 \%)$ \\
\hline \multirow[t]{2}{*}{ Total condensed tannins/total tannin determination } & Julkunen-Tiitto (1985) & $2(6.3 \%)$ \\
\hline & Others & $4(12.5 \%)$ \\
\hline Total flavonol determination & Jimoh et al. (2010) & $3(9.4 \%)$ \\
\hline Oligomeric proanthocyanidin determination & Quettier-Deleu et al. (2000) & $2(6.3 \%)$ \\
\hline Total carotenoid determination & Al-Farsi et al. (2005) & $1(3.1 \%)$ \\
\hline \multirow[t]{5}{*}{ DPPH assay } & Brand-Williams et al. (1995) & $9(28.1 \%)$ \\
\hline & Blois (1958) & $3(9.4 \%)$ \\
\hline & Rodríguez et al. (2005) & $3(9.4 \%)$ \\
\hline & Mansouri et al. (2005) & $2(6.3 \%)$ \\
\hline & Others & $10(31.3 \%)$ \\
\hline \multirow[t]{5}{*}{ FRAP assay } & Benzie and Strain (1996) & $4(12.5 \%)$ \\
\hline & Benzie and Strain (1999) & $3(9.4 \%)$ \\
\hline & Oyaizu (1986) & $2(6.3 \%)$ \\
\hline & Siahpoosh and Javedani (2012) & $2(6.3 \%)$ \\
\hline & Others & $7(21.9 \%)$ \\
\hline \multirow[t]{2}{*}{ ABTS assay } & Re et al. (1999) & $7(21.9 \%)$ \\
\hline & Others & $4(12.5 \%)$ \\
\hline \multirow[t]{3}{*}{ Metal chelating assay } & Decker and Welch (1990) & $2(6.3 \%)$ \\
\hline & Kanatt et al. (2007) & $2(6.3 \%)$ \\
\hline & Others & $2(6.3 \%)$ \\
\hline \multirow[t]{2}{*}{ Phosphomolybdenum assay } & Prieto et al. (1999) & $4(12.5 \%)$ \\
\hline & Others & $1(3.1 \%)$ \\
\hline \multirow[t]{3}{*}{ Hydrogen peroxide assay } & Ruch et al. (1989) & $1(3.1 \%)$ \\
\hline & Kim et al. 2003 & $1(3.1 \%)$ \\
\hline & Kumaran and Karunakaran (2007) & $1(3.1 \%)$ \\
\hline \multirow[t]{3}{*}{ Superoxide anion assay } & Nishikimi et al. (1972) & $1(3.1 \%)$ \\
\hline & Le Bourvellec et al. (2008) & $1(3.1 \%)$ \\
\hline & Siahpoosh and Javedani (2012) & $1(3.1 \%)$ \\
\hline \multirow[t]{3}{*}{ CUPRAC assay } & Campos et al. (2009) & $1(3.1 \%)$ \\
\hline & Apak et al. (2014) & $1(3.1 \%)$ \\
\hline & Kurzawa et al. (2015) & $1(3.1 \%)$ \\
\hline \multirow[t]{2}{*}{$\beta$-Carotene bleaching assay } & Dapkevicius et al. (1998) & $1(3.1 \%)$ \\
\hline & Siddhuraju and Becker (2003) & $1(3.1 \%)$ \\
\hline \multirow[t]{2}{*}{ Hydroxyl radical assay } & Leong and Shui (2002) & $1(3.1 \%)$ \\
\hline & Murcia et al. (2002) & $1(3.1 \%)$ \\
\hline \multirow[t]{2}{*}{ Lipoperoxyl radical assay } & Patro et al. (2002) & $1(3.1 \%)$ \\
\hline & Martínez-Tomé et al. (2004) & $1(3.1 \%)$ \\
\hline AEAC assay & Gil et al. (2000) & $1(3.1 \%)$ \\
\hline
\end{tabular}

Moreover, it could help researchers to conduct potential systematic reviews and meta-analyses in this research area.

Determination of antioxidant content in natural foods such as ripe date fruits is a growing area of research which is important to increase the knowledge and understanding of the health benefits of these foods. The findings of this scoping review have several implications for future research practices. Firstly, it seems that there is an emerging trend in research publications that investigated antioxidant content determination in ripe date fruits during the past two decades. Based on our findings, available studies in this research area are still growing up in numbers and were conducted in a few countries (most of them from the Middle East and North Africa). Many of the selected studies were carried out mainly to determine antioxidant content in ripe date fruits. However, many studies were conducted to understand the effectiveness of certain 
Table 8 Measurement units used to quantify values of antioxidant components, antioxidant activity assays, and antioxidant compounds (phenolic compounds and flavonoid compounds) determined for collected ripe date fruit samples in selected studies that were included in the qualitative analysis in this scoping review $(n=32)$
Measurement units used to quantify values of*

Total phenol content

Total flavonoid content

Total condensed tannins/total tannin content

Total flavonol content

Oligomeric proanthocyanidin content Total carotenoid content DPPH assay

FRAP assay

ABTS assay

Metal chelating assay

Phosphomolybdenum assay

Hydrogen peroxide assay

\begin{tabular}{|c|c|}
\hline mg GAE/100 g FW & $11(34.4 \%)$ \\
\hline $\mathrm{mg} \mathrm{GAE} / 100 \mathrm{~g} \mathrm{DW}$ & $11(34.4 \%)$ \\
\hline $\mathrm{mg} \mathrm{GAE} / 100 \mathrm{~g}$ extract & $1(3.1 \%)$ \\
\hline$\mu \mathrm{g} \mathrm{GAE} / \mathrm{mg} \mathrm{DW}$ & $2(6.3 \%)$ \\
\hline mg TAE/100 g FW & $1(3.1 \%)$ \\
\hline mg TAE/g dry extract & $2(6.3 \%)$ \\
\hline $\mathrm{mg} \mathrm{CAE} / 100 \mathrm{~g} \mathrm{FW}$ & $1(3.1 \%)$ \\
\hline $\mathrm{mg} / 100 \mathrm{~g} \mathrm{FW}$ & $1(3.1 \%)$ \\
\hline $\mathrm{mg} / 100 \mathrm{~g} \mathrm{DW}$ & $2(6.3 \%)$ \\
\hline mg QE/100 g FW & $2(6.3 \%)$ \\
\hline $\mathrm{mg} \mathrm{QE} / 100 \mathrm{~g} \mathrm{DW}$ & $3(9.4 \%)$ \\
\hline $\mathrm{mg} \mathrm{CE} / 100 \mathrm{~g} \mathrm{FW}$ & $2(6.3 \%)$ \\
\hline $\mathrm{mg} \mathrm{CE} / 100 \mathrm{~g} \mathrm{DW}$ & $4(12.5 \%)$ \\
\hline $\mathrm{mg} \mathrm{CE} / 100 \mathrm{~g}$ extract & $1(3.1 \%)$ \\
\hline mg RE/100 g DW & $1(3.1 \%)$ \\
\hline mg RE/100 g dry extract & $2(6.3 \%)$ \\
\hline $\mathrm{mg} / 100 \mathrm{~g} \mathrm{DW}$ & $2(6.3 \%)$ \\
\hline $\mathrm{mg} \mathrm{CE} / 100 \mathrm{~g} \mathrm{FW}$ & $2(6.3 \%)$ \\
\hline $\mathrm{mg} \mathrm{CE} / 100 \mathrm{~g} \mathrm{DW}$ & $2(6.3 \%)$ \\
\hline mg CYE/100 g DW & $1(3.1 \%)$ \\
\hline mg GAE/100 g extract & $1(3.1 \%)$ \\
\hline $\mathrm{mg} \mathrm{RE} / 100 \mathrm{~g} \mathrm{FW}$ & $1(3.1 \%)$ \\
\hline mg RE/100 g DW & $2(6.3 \%)$ \\
\hline $\mathrm{mg}$ of CYE/100 mg dry extract & $2(6.3 \%)$ \\
\hline $\mathrm{mg} / 100 \mathrm{~g} \mathrm{FW}$ & $1(3.1 \%)$ \\
\hline Scavenging capacity (inhibition \%) & $6(18.8 \%)$ \\
\hline $\mathrm{AE}(=1 / \mathrm{IC} 50)$ & $4(12.5 \%)$ \\
\hline IC50 ( $\mu \mathrm{g} / \mathrm{mL})$ & $5(15.6 \%)$ \\
\hline IC50 (g/L) & $2(6.3 \%)$ \\
\hline IC50 $(\mathrm{mg} / \mathrm{mL}) \mathrm{FW}$ & $1(3.1 \%)$ \\
\hline IC50 $(\mathrm{mg} / \mathrm{mL})$ extract & $2(6.3 \%)$ \\
\hline IC50 ( $\mu \mathrm{g} \mathrm{GAE} / \mathrm{mL})$ & $1(3.1 \%)$ \\
\hline$\mu \mathrm{mol} \mathrm{TE} / 100 \mathrm{~g} \mathrm{FW}$ & $2(6.3 \%)$ \\
\hline$\mu \mathrm{mol} \mathrm{TE} / 100 \mathrm{~g}$ DW & $1(3.1 \%)$ \\
\hline mmol TE/kg FW & $2(6.3 \%)$ \\
\hline $\mathrm{mmol} \mathrm{TE} / \mathrm{kg} \mathrm{DW}$ & $1(3.1 \%)$ \\
\hline Scavenging capacity (inhibition \%) & $1(3.1 \%)$ \\
\hline mg GAE/100 g DW & $1(3.1 \%)$ \\
\hline IC50 ( $\mu \mathrm{g}$ GAE/mL) & $1(3.1 \%)$ \\
\hline IC50 (g/L) & $1(3.1 \%)$ \\
\hline IC50 (mg/mL) & $3(9.4 \%)$ \\
\hline$\mu \mathrm{mol} \mathrm{TE} / 100 \mathrm{~g} \mathrm{FW}$ & $1(3.1 \%)$ \\
\hline$\mu \mathrm{mol} \mathrm{TE} / 100 \mathrm{~g} \mathrm{DW}$ & $1(3.1 \%)$ \\
\hline mmol TE/kg FW & $1(3.1 \%)$ \\
\hline $\mathrm{mmol} / 100 \mathrm{~g} \mathrm{FW}$ & $1(3.1 \%)$ \\
\hline$\mu \mathrm{mol} / 100 \mathrm{~g} \mathrm{DW}$ & $3(9.4 \%)$ \\
\hline $\mathrm{mmol} / 100 \mathrm{~g}$ extract & $1(3.1 \%)$ \\
\hline Absorbance measured at $700 \mathrm{~nm}$ & $2(6.3 \%)$ \\
\hline Absorbance measured at $593 \mathrm{~nm}$ & $1(3.1 \%)$ \\
\hline Scavenging capacity (inhibition \%) & $1(3.1 \%)$ \\
\hline IC50 $(\mu \mathrm{g} / \mathrm{mL})$ & $2(6.3 \%)$ \\
\hline$\mu \mathrm{mol} \mathrm{TE} / 100 \mathrm{~g} \mathrm{FW}$ & $4(12.5 \%)$ \\
\hline$\mu \mathrm{mol} \mathrm{TE} / 100 \mathrm{~g} \mathrm{DW}$ & $3(9.4 \%)$ \\
\hline $\mathrm{mmol} \mathrm{TE} / 100 \mathrm{~g} \mathrm{FW}$ & $1(3.1 \%)$ \\
\hline Chelating activity (inhibition \%) & $2(6.3 \%)$ \\
\hline $\mathrm{IC} 50(\mu \mathrm{g} / \mathrm{mL})$ & $2(6.3 \%)$ \\
\hline IC50 (g/L) & $1(3.1 \%)$ \\
\hline IC50 $(\mathrm{mg} / \mathrm{mL})$ extract & $1(3.1 \%)$ \\
\hline Scavenging capacity (inhibition \%) & $1(3.1 \%)$ \\
\hline IC50 $(g / L)$ & $1(3.1 \%)$ \\
\hline mg AAE/g FW & $1(3.1 \%)$ \\
\hline$\mu \mathrm{mol}$ AAE/g extract & $1(3.1 \%)$ \\
\hline Absorbance measured at $695 \mathrm{~nm}$ & $1(3.1 \%)$ \\
\hline Scavenging capacity (inhibition \%) & $2(6.3 \%)$ \\
\hline IC50 (mg/mL) extract & $1(3.1 \%)$ \\
\hline
\end{tabular}

Frequency N (\%)

$1(34.4 \%)$

(6.3\%)

$2(6.3 \%)$

$(6.4 \%$

(3.1\%)

$(3.1 \%)$

$2(6.3 \%)$

$1(3.1 \%)$

$2(6.3 \%)$

$2(6.3 \%)$

$4(12.5 \%)$

$(5.6 \%)$

$2(6.3 \%)$

$(3.1 \%)$

$1(3.1 \%)$

$(3.1 \%)$

$1(3.1 \%)$

$3(9.4 \%)$

$(3.1 \%)$

$(3.1 \%)$

(6.3\%)

$1(3.1 \%)$

$3(9.4 \%)$

$1(3.1 \%)$

(3.1\%)

(3.1\%)

$1(3.1 \%)$ 
Table 8 (continued)

\begin{tabular}{lll}
\hline Measurement units used to quantify values of* & & Frequency N (\%) \\
\hline Superoxide anion assay & Scavenging capacity (inhibition \%) & $1(3.1 \%)$ \\
& $\mathrm{IC5} 5(\mu \mathrm{g} / \mathrm{mL})$ & $1(3.1 \%)$ \\
& $\mathrm{mg} / \mathrm{L}$ & $1(3.1 \%)$ \\
CUPRAC assay & Scavenging capacity (inhibition \%) & $1(3.1 \%)$ \\
& $\mathrm{IC50}(\mu \mathrm{g} / \mathrm{mL})$ & $1(3.1 \%)$ \\
& $\mathrm{IC50}(\mathrm{g} / \mathrm{L})$ & $1(3.1 \%)$ \\
$\beta$-Carotene bleaching assay & Scavenging capacity (inhibition $\%)$ & $2(6.3 \%)$ \\
Hydroxyl radical assay & Scavenging capacity (inhibition $\%)$ & $2(6.3 \%)$ \\
Lipoperoxyl radical assay & Scavenging capacity (inhibition $\%)$ & $1(3.1 \%)$ \\
& $\mathrm{IC} 50(\mathrm{mg} / \mathrm{mL})$ & $1(3.1 \%)$ \\
AEAC assay & $\mathrm{mg} \mathrm{AAE} / 100 \mathrm{~g}$ FW & $1(3.1 \%)$ \\
Phenolic compound content & $\mathrm{mg} / 100 \mathrm{~g} \mathrm{FW}$ & $4(12.5 \%)$ \\
Flavonoid compound content & $\mathrm{mg} / 100 \mathrm{~g} \mathrm{DW}$ & $3(9.4 \%)$ \\
& $\mathrm{mg} / 100 \mathrm{~g} \mathrm{FW}$ & $1(3.1 \%)$ \\
& $\mathrm{mg} / 100 \mathrm{~g} \mathrm{DW}$ & $3(9.4 \%)$ \\
\hline
\end{tabular}

* $F W$ fresh weight; $D W$ dry weight; $G A E$ gallic acid equivalents; $T A E$ tannic acid equivalents; $C A E$ caffeic acid equivalent; $Q E$ quercetin equivalents; $C E$ catechin equivalents; $R E$ rutin equivalents; $C Y E$ cyanidin equivalents; $A A E$ ascorbic acid equivalents; $T E$ trolox equivalents; $A E$ antiradical efficiency; $I C 50$ inhibition concentration (concentration providing $50 \%$ inhibition)

variables such as ripening stages and extraction solvents. Therefore, more academic efforts, especially from researchers in the field of food science, are required to develop the research activities in this area of research.

Secondly, collected ripe date fruit samples in different studies are likely to be highly variable in their characteristics. It was noted that not only the number of collected ripe date fruit cultivars in each selected study was variable, but also the type of collected cultivars was highly variable in different studies. Although the information about quality, harvest season, local location, source, storage periods and temperature before analysis, and moisture/dry matter content of collected ripe date fruit samples was missing in many studies, there were variations in reported information about collected ripe date fruit samples among different studies. For example, information about storage periods before analysis was missing in twentynine selected studies $(90.6 \%)$. In addition, there was an obvious variation in this period between the three studies that reported this information. Al-Najada and Mohamed (2014) observed that total phenolic content and flavonoid content of fresh date fruits of two Saudi cultivars (Khalas and Shishi) were increased, while antioxidant activity, measured by DPPH and FRAP assays, was decreased during storage for 6 and 12 months at $4{ }^{\circ} \mathrm{C}$. Unfortunately, the absence of important information about characteristics of collected ripe date fruit samples in many studies may have a negative effect on the impact of their results. In addition, high variability in these characteristics makes it hard to compare results of different studies. Therefore, more focus on reporting all characteristics of collected ripe date fruit samples in future studies is needed. Furthermore, attempts to limit differences in these characteristics and producing standard characteristics to follow are highly recommended to enhance the research quality and reproducibility in this area of research.

Thirdly, the current review found that the solvents used to extract antioxidant content from collected ripe date fruit samples varied in their types and their concentrations among different studies. Despite that the methanolic solvents, especially solvent with $80 \%$ concentration, were commonly used in selected studies, other solvents and other concentrations were still used to extract antioxidant content from collected ripe date fruit samples. According to Kchaou et al. (2013), the total
Table 9 Data presentation methods used to report values of moisture/dry matter content, antioxidant components, antioxidant activity assays, and antioxidant compounds (phenolic compounds and flavonoid compounds) determined for collected ripe date fruit samples in selected studies that were included in the qualitative analysis in this scoping review $(n=32)$

\begin{tabular}{lll}
\hline Data presentation methods used to report values of & & Frequency N (\%) \\
\hline Moisture/dry matter content & Tables & $7(21.9 \%)$ \\
& Bar graphs & $3(9.6 \%)$ \\
Antioxidant component content & Tables & $26(81.3 \%)$ \\
& Bar graphs & $6(18.8 \%)$ \\
Antioxidant activity assays & Tables & $24(75.0 \%)$ \\
& Bar graphs & $8(25.0 \%)$ \\
Phenolic compound content & Tables & $7(21.9 \%)$ \\
Flavonoid compound content & Tables & $4(12.5 \%)$
\end{tabular}


phenolic content and antioxidant activity varied greatly when five different solvents were used to extract antioxidant content from six ripe Tunisian date fruit cultivars which indicate a possible effect of extracting solvent on results. In addition, antioxidant content in three ripe Saudi date fruit cultivars (Sefri, Sari, and Ruzeiz) was extracted by using five different solvents. They noted that wide ranging of total phenolic content and antioxidant activity were reported when different solvents are used (Ali et al. 2016). Similarly, antioxidant content in two ripe Iranian date fruit cultivars (Berhi and Kabkab) was extracted by using three different solvents. Results indicate that the contents of total phenols, total flavonoids, and oligomeric proanthocyanidins in addition to antioxidant activity were highly varied based on the used solvent (Siahpoosh et al. 2016a; Siahpoosh et al. 2016b). The same finding was reported by Hachani et al. (2018) in five ripe Algerian date fruit cultivars concerning total phenolic content, total flavonoid content, condensed tannin content, antioxidant activity, phenolic compounds, and flavonoid compounds (Hachani et al. 2018).

Kchaou et al. (2013) reported that acetone $70 \%$ was found to be the most effective solvent compared with other used solvents to extract total phenols (199.43-576.48 mg GAE/ $100 \mathrm{~g} \mathrm{FW}$ ). Contrarily, ethanol $100 \%$ was found to be the least efficient solvent for extracting total phenols (54.73$93.82 \mathrm{mg} \mathrm{GAE} / 100 \mathrm{~g} \mathrm{FW}$ ). The antioxidant activity was measured using DPPH, FRAP, and phosphomolybdenum assays. Both acetone $70 \%$ and methanol $50 \%$ extracts had strong DPPH free radical scavenging activities. Results of FRAP assay showed that the best reducing power was obtained by acetone $70 \%$ for the six studied cultivars compared with methanol 50\%. When antioxidant activities of different five solvent extracts were measured using phosphomolybdenum assay, methanol $50 \%$ was found with the highest total antioxidant for all studied cultivar date, followed by methanol $88 \%$ and acetone $70 \%$. On the other hand, absolute ethanol and water gave the lowest antioxidant activity among the used solvent. Their results suggest that acetone $70 \%$ and methanol $50 \%$ could be the solvents of choice in all subsequent experiments (Kchaou et al. 2013). Unfortunately, antioxidant content results drawn from different studies cannot be compared when different extracting solvents are used. Therefore, more research to investigate the possible effect for extracting solvents on antioxidants is needed. Furthermore, producing a standard solvent extraction procedure to follow is highly recommended to improve the research quality and reproducibility in this area of research.

Fourthly, very high inconsistency and variability were noted in reported information about determining antioxidant content and the used analytical methods, citation references for procedures, measurement units, and data presentation methods. The first place to locate a high inconsistency among selected studies is information reported about numbers and types of antioxidant components, antioxidant activity assays, and antioxidant compounds determined for collected ripe date fruit samples. Although total phenol content was reported in all selected studies, there was high variability in numbers and types of antioxidant components that were reported in each included study. The variability looks like more noticeable in the information reported about numbers and types of antioxidant activity assays that were reported in each included study. While DPPH assay was reported in the vast majority of selected studies, the appearance of other assays is still highly variable among different studies. Even though information about phenolic and flavonoid compounds was reported in a limited number of studies, inconsistency is still observed in numbers and types of compounds determined in different studies. The second place to find a high inconsistency among selected studies is information reported about analytical methods used to determine antioxidant components for collected ripe date fruit samples. Colorimetric methods were the common analytical methods used to determine antioxidant components. However, some studies determined total phenol content and total flavonoid content by using HPLC. Moreover, several types of reagents were used through colorimetric methods to determine total condensed tannins/total tannins. The third place to detect a high inconsistency among selected studies is citation references for procedures related to solvent extraction, antioxidant component determination, and antioxidant activity assays applied on collected ripe date fruit samples. Actually, some references were frequently used to cite certain analytical procedure in selected studies. For example, one reference (Singleton and Rossi 1965) was used commonly to cite total phenol determination procedure, and another reference (Brand-Williams et al. 1995) was used commonly to cite DPPH assay procedure. However, high variability in used references still can be seen in selected studies. It is important to cite the source(s) followed to run any analytical procedure in order to allow other researchers to track down and reproduce them, especially when some details of these analytical procedures are omitted in published articles. In addition, choosing the best source(s) to cite is crucial to avoid high dispersion and disparity in the used analytical procedure. The best source(s) to cite could be the article(s) that contribute significantly to develop or improve the analytical procedure (Bryson 2012; Santini 2018). Therefore, following good citation practices for any used analytical procedures when writing future articles is highly recommended.

Another major source of inconsistency and variability among selected studies is measurement units used to quantify the values of antioxidant components, antioxidant activity assays, and antioxidant compounds determined for collected ripe date fruit samples. Measurement refers to a technique used to determine a specific property of an object by comparing it to a standard. Accordingly, the measurement unit refers to a fixed magnitude of a quantity used as a standard for 
quantitative measurement of the same kind. Both of them are important because, without correct measurement and suitable units to express them, qualitative assessment for any property cannot be done (Humphry 2013; Mari et al. 2018). Furthermore, when more than one measurement unit are used to measure a specific property, it is important to be able to convert between them easily and quickly in order to make comparing results from different sources possible and effective. In the selected studies, wide range of measurement units were used to express amounts of antioxidant content in collected ripe date fruit samples. While converting quantities from certain measurement unit to another can be handled easily and quickly, the conversion between many reported measurement units could be complex and difficult. For example, total phenol content was reported by using nine measurement units in different selected studies; two of them are mg GAE/ $100 \mathrm{~g} \mathrm{DW}$ and $\mu \mathrm{g}$ GAE/mg DW. Conversion between them can be simply done. Another measurement unit used to report amounts of total phenol content was mg GAE/100 g FW. Conversion of this unit to $\mathrm{mg}$ GAE/100 g DW can be completed only if the moisture or dry matter content of the collected date fruits is known. In another example, total flavonoid content was reported by using eight measurement units in different selected studies; two of them are mg QE/100 g DW and $\mathrm{mg} \mathrm{CE} / 100 \mathrm{~g} \mathrm{DW}$. Indeed, conversion between them is more complex and problematic. Therefore, reporting moisture or dry matter content in future articles and adopting standard measurement units to follow are highly recommended to advance the research quality and reproducibility in this area of research.

The last source of inconsistency among selected studies is data presentation methods used to report the values of moisture/dry matter content, antioxidant components, antioxidant activity assays, and antioxidant compounds determined for collected ripe date fruit samples. Despite that most of the values of moisture/dry matter content, antioxidant components, and antioxidant activity assays were reported by using tables, many of these values in many studies were reported only by using bar graphs. Bar graph or bar chart is a graphical display of data using bars of different heights to represent actual values. Bar graphs are considered an effective method for data presentation. However, a major issue with bar graphs is how to extract the actual numerical values, especially when these values were not reported numerically in the article text. Usually, researchers extract the numerical values from bar graphs either manually by using a ruler or automatically by using specialized programs or online tools such as Web Plot Digitizer (Rohatgi 2019). Data errors are still expected when numerical values are extracted from bar graphs. In addition, numerical value extraction, in some cases, becomes almost unavailable due to poor bar graph presentation. An example is extracting values of total phenol content from bar graph in one of the selected studies (Farag et al. 2016). Therefore, presenting result values in future articles by using tables to make them easily available for other researchers is highly recommended. When bar graphs are used, it is important to use clear and easy to understand bar graphs and to ensure that the values that were reported in bar graphs are numerically available in the bar graphs themselves or in text or provided in an attached supplementary document.

A few challenges and limitations were met during the synthesis of the current scoping review. Firstly, only three reputable electronic databases (Scopus, PubMed, and Web of Science) were searched to ensure selecting articles of good quality. Limiting the search of sources to these databases could affect our results. Secondly, many studies were excluded during the study selection stage based on inclusion criteria for various reasons such as missing information about the maturation stage or cultivar type of collected samples in these articles. The high rate of study exclusion could affect our findings. Thirdly, some authors published several selected articles. These articles could be based on the same study, which may also affect our results. However, the finding informed in this scoping review is still valuable and will contribute significantly to promote higher research design consistency and thus, improve research quality in the area of antioxidant content determination in future articles.

\section{Conclusions}

In the light of emerging research trend in the area of antioxidant content determination, high inconsistency and variability were observed in various characteristics of the selected studies, collected ripe date fruit samples, and extraction solvents, as well as information about determining antioxidant content (quantity and quality) and the used analytical methods, citation references for procedures, measurement units, and data presentation methods. Furthermore, the research gaps and future recommendations to promote higher research design consistency and improve research quality in this area of research have been described and discussed carefully.

While it was common to determine antioxidant components such as total phenols and total flavonoids in ripe date fruits by using colorimetric methods, which is a simple, rapid, and low-cost method, there is a growing tendency to use chromatographic methods such as HPLC which is more sophisticated, reproducible, and costly methods to determine both antioxidant components and antioxidant compounds (phenolic compounds and flavonoid compounds). Ripe date fruits are one promising food source of valuable components such as antioxidants and dietary fiber. Many attempts try to use these components after utilization with necessary pre-treatments as nutraceuticals or supplements for various applications in the food industry. The future trends go to investigate the proper 
procedures to extract and utilize these active components in date fruits.

Author Contributions Conceptualization: NAA. and JZA.; methodology: RAA.; software: NaAA.; validation: LAA., FAA., and JZA.; formal analysis: NaAA.; investigation: RAA.; resources: NAA.; data curation: JZA.; writing - original draft preparation: NAA, JZA., FAA., and LAA.; writing - review and editing: NAA.; visualization: NaAA.; supervision: NAA.; project administration: NAA.; funding acquisition: NAA. All authors have read and agreed to the published version of the manuscript.

Funding This research was funded by the Ministry of Environment, Water, and Agriculture, Kingdom of Saudi Arabia, grant number T-A-1 and the Deanship of Scientific Research at Princess Nourah bint Abdulrahman University through the Fast-track Research Funding Program.

Data Availability Not applicable.

\section{Compliance with Ethical Standards}

Conflict of Interest Nora Abdullah AlFaris declares that she no conflict of interest. Jozaa Zaidan AlTamimi declares that she has no conflict of interest. Lujain Abdulaziz AlMousa declares that he has no conflict of interest. Fatima Ali AlGhamidi declares that she has no conflict of interest. Riyadh A. Alzaheb declares that he has no conflict of interest. Najla Abdullah Albaridi declares that he has no conflict of interest.

Ethical Approval This article does not contain any studies with human participants or animals performed by any of the authors.

Informed Consent Not applicable.

Code Availability Not applicable.

Open Access This article is licensed under a Creative Commons Attribution 4.0 International License, which permits use, sharing, adaptation, distribution and reproduction in any medium or format, as long as you give appropriate credit to the original author(s) and the source, provide a link to the Creative Commons licence, and indicate if changes were made. The images or other third party material in this article are included in the article's Creative Commons licence, unless indicated otherwise in a credit line to the material. If material is not included in the article's Creative Commons licence and your intended use is not permitted by statutory regulation or exceeds the permitted use, you will need to obtain permission directly from the copyright holder. To view a copy of this licence, visit http://creativecommons.org/licenses/by/4.0/.

\section{References}

Abbas FMA, Foroogh B, Liong MT, Azhar ME (2008) Multivariate statistical analysis of antioxidants in dates (Phoenix dactylifera). Int Food Res J 15(2):193-200

Al Harthi SS, Mavazhe A, Al Mahroqi H, Khan SA (2015) Quantification of phenolic compounds, evaluation of physicochemical properties and antioxidant activity of four date (Phoenix dactylifera L.) varieties of Oman. J Taibah Univ Med Sci 10(3):346-352

Aldhafiri FK (2017) Evaluation of biochemical parameters, phenolic compounds and antioxidant capacity of some varieties of Phoenix dactylifera L. (date fruits) to determine the nutritional impact values. Mediterr J Nutr Metab 10(2):153-164

Al-Farsi MA, Lee CY (2008) Nutritional and functional properties of dates: a review. Crit Rev Food Sci Nutr 48(10):877-887

Al-Farsi M, Alasalvar C, Morris A, Baron M, Shahidi F (2005) Comparison of antioxidant activity, anthocyanins, carotenoids, and phenolics of three native fresh and sun-dried date (Phoenix dactylifera L.) varieties grown in Oman. J Agric Food Chem 53(19):7592-7599

Al-Farsi M, Alasalvar C, Al-Abid M, Al-Shoaily K, Al-Amry M, AlRawahy F (2007) Compositional and functional characteristics of dates, syrups, and their by-products. Food Chem 104:943-947

Al-Farsi K, Al-Habsi NA, Al-Khusaibi M (2018) The potential antioxidant properties of date products: a concise update. Can J Clin Nutr 6: 84-104

Ali DMH, Momen AA, Khalid MAA (2016) Antioxidant activity and total phenolic content of date palm (Phoenix dactylifera L.) fruits from Taif Governorate, Saudi Arabia. Res J Pharm, Biol Chem Sci 7(3):1708-1721

Allaith AAA (2008) Antioxidant activity of Bahraini date palm (Phoenix dactylifera L.) fruit of various cultivars. Int J Food Sci Technol 43(6):1033-1040

Allaith A (2019) Antioxidants in date fruits and the extent of the variability of the total phenolic Content: Review and Analysis. In: Antioxidants. IntechOpen. https://doi.org/10.5772/intechopen. 83851

Al-Mssallem MQ, Alqurashi RM, Al-Khayri JM (2020) Bioactive compounds of date palm (Phoenix dactylifera L.). Bioact Compd Underutilized Fruits Nuts:91-105

Al-Najada AR, Mohamed SA (2014) Changes of antioxidant capacity and oxidoreductases of Saudi date cultivars (Phoenix dactylifera L.) during storage. Sci Hortic 170:275-280

Al-Shahib W, Marshall RJ (2003) The fruit of the date palm: its possible use as the best food for the future? Int J Food Sci Nutr 54(4):247259

Al-Shwyeh HA (2019) Date palm (Phoenix dactylifera L.) fruit as potential antioxidant and antimicrobial agents. J Pharm Bioallied Sci 11(1):1

Al-Turki S, Shahba MA, Stushnoff C (2010) Diversity of antioxidant properties and phenolic content of date palm (Phoenix dactylifera L.) fruits as affected by cultivar and location. J Food Agric Environ 8(1):253-260

Apak R, Özyürek M, Güçlü K, Bekdeșer B, Bener M (2014) The CUPRAC methods of antioxidant measurement for beverages. In: Processing and impact on antioxidants in beverages. Academic Press, pp 235-244

Arksey H, O'Malley L (2005) Scoping studies: towards a methodological framework. Int J Soc Res Methodol 8(1):19-32

Baliga MS, Baliga BRV, Kandathil SM, Bhat HP, Vayalil PK (2011) A review of the chemistry and pharmacology of the date fruits (Phoenix dactylifera L.). Food Res Int 44(7):1812-1822

Barros L (2020) Natural antioxidants and human health effects. Curr Pharm Des 26(16):1757-1758

Benmeddour Z, Mehinagic E, Le Meurlay D, Louaileche H (2013) Phenolic composition and antioxidant capacities of ten Algerian date (Phoenix dactylifera L.) cultivars: a comparative study. J Funct Foods 5(1):346-354

Benmeziane-Derradji F (2019) Nutritional value, phytochemical composition, and biological activities of Middle Eastern and North African date fruit: an overview. Euro Mediterr J Environ Integr 4(1):39

Benzie IF, Strain JJ (1996) The ferric reducing ability of plasma (FRAP) as a measure of "antioxidant power": the FRAP assay. Anal Biochem 239(1):70-76

Benzie IF, Strain JJ (1999) [2] Ferric reducing/antioxidant power assay: direct measure of total antioxidant activity of biological fluids and modified version for simultaneous measurement of total antioxidant 
power and ascorbic acid concentration. In: Methods in enzymology, vol 299. Academic Press, pp 15-27

Biglari F, AlKarkhi AF, Easa AM (2008) Antioxidant activity and phenolic content of various date palm (Phoenix dactylifera) fruits from Iran. Food Chem 107(4):1636-1641

Blois MS (1958) Antioxidant determinations by the use of a stable free radical. Nature 181(4617):1199-1200

Bouhlali ET, Ramchoun M, Alem C, Ghafoor K, Ennassir J, Zegzouti YF (2017) Functional composition and antioxidant activities of eight Moroccan date fruit varieties (Phoenix dactylifera L.). J Saudi Soc Agric Sci 16(3):257-264

Brand-Williams W, Cuvelier ME, Berset CLWT (1995) Use of a free radical method to evaluate antioxidant activity. LWT Food Sci Technol 28(1):25-30

Bryson D (2012) Using research papers: citations, referencing and plagiarism. J Vis Commun Med 35(2):82-84

Campos C, Guzmán R, López-Fernández E, Casado Á (2009) Evaluation of the copper (II) reduction assay using bathocuproinedisulfonic acid disodium salt for the total antioxidant capacity assessment: the CUPRAC-BCS assay. Anal Biochem 392(1):37-44

Chaira N, Smaali MI, Martinez-Tomé M, Mrabet A, Murcia MA, Ferchichi A (2009) Simple phenolic composition, flavonoid contents and antioxidant capacities in water-methanol extracts of Tunisian common date cultivars (Phoenix dactylifera L.). Int J Food Sci Nutr 60(sup7):316-329

Chao CT, Krueger RR (2007) The date palm (Phoenix dactylifera L.): overview of biology, uses, and cultivation. Hort Sci 42(5):10771082

Dapkevicius A, Venskutonis R, van Beek TA, Linssen JP (1998) Antioxidant activity of extracts obtained by different isolation procedures from some aromatic herbs grown in Lithuania. J Sci Food Agric 77(1):140-146

Decker EA, Welch B (1990) Role of ferritin as a lipid oxidation catalyst in muscle food. J Agric Food Chem 38(3):674-677

El Arem A, Saafi EB, Mechri B, Lahouar L, Issaoui M, Hammami M, Achour L (2012) Effects of the ripening stage on phenolic profile, phytochemical composition and antioxidant activity of date palm fruit. J Agric Food Chem 60(44):10896-10902

Farag MA, Handoussa H, Fekry MI, Wessjohann LA (2016) Metabolite profiling in 18 Saudi date palm fruit cultivars and their antioxidant potential via UPLC-qTOF-MS and multivariate data analyses. Food Funct 7(2):1077-1086

Ghiaba Z, Yousfi M, Hadjadj M, Saidi M (2014) Study of antioxidant properties of five Algerian date (phoenix dactylifera $\mathrm{L}$ ) cultivars by cyclic voltammetric technique. Int J Electrochem Sci 9:909-920

Gil MI, Tomás-Barberán FA, Hess-Pierce B, Holcroft DM, Kader AA (2000) Antioxidant activity of pomegranate juice and its relationship with phenolic composition and processing. J Agric Food Chem 48(10):4581-4589

Hachani S, Hamia C, Boukhalkhal S, Silva AM, Djeridane A, Yousfi M (2018) Morphological, physico-chemical characteristics and effects of extraction solvents on UHPLC-DAD-ESI-MSn profiling of phenolic contents and antioxidant activities of five date cultivars (Phoenix dactylifera L.) growing in Algeria. NFS J 13:10-22

Haider MS, Khan IA, Jaskani MJ, Naqvi SA, Mateen S, Shahzad U, Abbas H (2018) Pomological and biochemical profiling of date fruits (Phoenix dactylifera L.) during different fruit maturation phases. Pak J Bot 50(3):1069-1076

Haimoud SA, Allem R, Merouane A (2016) Antioxidant and antiinflammatory properties of widely consumed date palm (Phoenix dactylifera L.) fruit varieties in Algerian oases. J Food Biochem 40(4):463-471

Hamad I, AbdElgawad H, Al Jaouni S, Zinta G, Asard H, Hassan S et al (2015) Metabolic analysis of various date palm fruit (Phoenix dactylifera L.) cultivars from Saudi Arabia to assess their nutritional quality. Molecules 20(8):13620-13641
Hamza H, Mrabet A, Jiménez-Araujo A (2016) Date palm parthenocarpic fruits (Phoenix dactylifera L.) cv. Deglet Nour: chemical characterization, functional properties and antioxidant capacity in comparison with seeded fruits. Sci Hortic 211:352-357

Hemmateenejad B, Karimi S, Javidnia K, Parish M, Khademi R (2015) Classification and assessment of antioxidant activity and phenolic content of different varieties of date palm (Phoenix dactylifera) fruits from Iran. J Iran Chem Soc 12(11):1935-1943

Hong YJ, Tomas-Barberan FA, Kader AA, Mitchel AE (2006) The flavonoid glycosides and procyanidin composition of Deglet Noor dates (Phoenix dactylifera). J Agric Food Chem 54:2405-2411

Humphry S (2013) Understanding measurement in light of its origins. Front Psychol 4:113

Hussain MI, Farooq M, Syed QA (2020) Nutritional and biological characteristics of the date palm fruit (Phoenix dactylifera L.)-a review. Food Biosci 34:100509

Jimoh FO, Adedapo AA, Afolayan AJ (2010) Comparison of the nutritional value and biological activities of the acetone, methanol and water extracts of the leaves of Solanum nigrum and Leonotis leonorus. Food Chem Toxicol 48(3):964-971

Julkunen-Tiitto R (1985) Phenolic constituents in the leaves of northern willows: methods for the analysis of certain phenolics. J Agric Food Chem 33(2):213-217

Kanatt SR, Chander R, Sharma A (2007) Antioxidant potential of mint (Mentha spicata L.) in radiation-processed lamb meat. Food Chem 100(2):451-458

Kchaou W, Abbès F, Blecker C, Attia H, Besbes S (2013) Effects of extraction solvents on phenolic contents and antioxidant activities of Tunisian date varieties (Phoenix dactylifera L.). Ind Crop Prod 45:262-269

Kchaou W, Abbès F, Attia H, Besbes S (2014) In vitro antioxidant activities of three selected dates from Tunisia (Phoenix dactylifera L.). J Chem 2014:367681

Kim D-O, Jeong SW, Lee CY (2003) Antioxidant capacity of phenolic phytochemicals from various cultivars of plums. Food Chem 81(3): 321-326

Kumaran A, Karunakaran RJ (2007) In vitro antioxidant activities of methanol extracts of five Phyllanthus species from India. LWT Food Sci Technol 40(2):344-352

Kurzawa M, Filipiak-Szok A, Kłodzińska E, Szłyk E (2015) Determination of phytochemicals, antioxidant activity and total phenolic content in Andrographis paniculata using chromatographic methods. J Chromatogr B 995:101-106

Le Bourvellec C, Hauchard D, Darchen A, Burgot JL, Abasq ML (2008) Validation of a new method using the reactivity of electrogenerated superoxide radical in the antioxidant capacity determination of flavonoids. Talanta 75(4):1098-1103

Lee J, Koo N, Min DB (2004) Reactive oxygen species, aging, and antioxidative nutraceuticals. Compr Rev Food Sci Food Saf 3(1): 21-33

Lemine FMM, Ahmed MVOM, Maoulainine LBM, Bouna ZEAO, Samb A, Boukhary AOMSO (2014) Antioxidant activity of various Mauritanian date palm (Phoenix dactylifera L.) fruits at two edible ripening stages. Food Sci Nutr 2(6):700-7005

Leong LP, Shui G (2002) An investigation of antioxidant capacity of fruits in Singapore markets. Food Chem 76(1):69-75

Levac D, Colquhoun H, O’Brien KK (2010) Scoping studies: advancing the methodology. Implement Sci 5(1):69

Liu Z, Ren Z, Zhang J, Chuang CC, Kandaswamy E, Zhou T, Zuo L (2018) Role of ROS and nutritional antioxidants in human diseases. Front Physiol 9:477

Mansouri A, Embarek G, Kokkalou E, Kefalas P (2005) Phenolic profile and antioxidant activity of the Algerian ripe date palm fruit (Phoenix dactylifera). Food Chem 89(3):411-420 
Maqsood S, Adiamo O, Ahmad M, Mudgil P (2020) Bioactive compounds from date fruit and seed as potential nutraceutical and functional food ingredients. Food Chem 308:125522

Mari L, Ehrlich C, Pendrill L (2018) Measurement units as quantities of objects or values of quantities: a discussion. Metrologia 55(5):716721

Martínez-Tomé M, Murcia MA, Frega N, Ruggieri S, Jiménez AM, Roses F, Parras P (2004) Evaluation of antioxidant capacity of cereal brans. J Agric Food Chem 52(15):4690-4699

Mrabet A, Rodríguez-Arcos R, Guillén-Bejarano R, Chaira N, Ferchichi A, Jiménez-Araujo A (2012) Dietary fiber from Tunisian common date cultivars (Phoenix dactylifera L.): chemical composition, functional properties, and antioxidant capacity. J Agric Food Chem 60(14):3658-3664

Mrabet A, Rodríguez-Gutiérrez G, Guillén-Bejarano R, Rodríguez-Arcos R, Ferchichi A, Sindic M, Jiménez-Araujo A (2015) Valorization of Tunisian secondary date varieties (Phoenix dactylifera L.) by hydrothermal treatments: new fiber concentrates with antioxidant properties. LWT Food Sci Technol 60(1):518-524

Murcia MA, Martinez-Tome M, Jimenez AM, Vera AM, Honrubia M, Parras P (2002) Antioxidant activity of edible fungi (truffles and mushrooms): losses during industrial processing. J Food Prot 65(10):1614-1622

Neeraj JP, Singh S, Singh J (2013) Role of free radicals and antioxidants in human health and disease. Int J Curr Res Rev 5(19):14-22

Nishikimi M, Rao NA, Yagi K (1972) The occurrence of superoxide anion in the reaction of reduced phenazine methosulfate and molecular oxygen. Biochem Biophys Res Commun 46(2):849-854

Oyaizu M (1986) Antioxidant activity of brewing products of glucosamine fractionated by organic solvents and thin-layer chromatography. Nippon Skokulin Kogyo Gakkaishi 35:771-775

Patro BS, Rele S, Chintalwar GJ, Chattopadhyay S, Adhikari S, Mukherjee T (2002) Protective activities of some phenolic 1, 3diketones against lipid peroxidation: possible involvement of the 1, 3-diketone moiety. Chembiochem 3(4):364-370

Prieto P, Pineda M, Aguilar M (1999) Spectrophotometric quantitation of antioxidant capacity through the formation of a phosphomolybdenum complex: specific application to the determination of vitamin E1. Anal Biochem 269:337-341

Quettier-Deleu C, Gressier B, Vasseur J, Dine T, Brunet C, Luyckx M, Cazin M, Cazin JC, Bailleul F, Trotin F (2000) Phenolic compounds and antioxidant activities of buckwheat (Fagopyrum esculentum Moench) hulls and flour. J Ethnopharmacol 72(1-2):35-42

Re R, Pellegrini N, Proteggente A, Pannala A, Yang M, Rice-Evans C (1999) Antioxidant activity applying an improved ABTS radical cation decolorization assay. Free Radic Biol Med 26(9-10):12311237

Rodríguez R, Jaramillo S, Rodríguez G, Espejo JA, Guillén R, Fernández-Bolaños J, Heredia A, Jiménez A (2005) Antioxidant activity of ethanolic extracts from several asparagus cultivars. J Agric Food Chem 53(13):5212-5217
Rohatgi A (2019) Web Plot Digitizer. Version: 4.2. Available at: https:// automeris.io/WebPlotDigitizer/index.html (Accessed in Oct 20, 2020)

Ruch RJ, Cheng SJ, Klaunig JE (1989) Prevention of cytotoxicity and inhibition of intercellular communication by antioxidant catechins isolated from Chinese green tea. Carcinogenesis 10(6):1003-1008

Saafi EB, El Arem A, Issaoui M, Hammami M, Achour L (2009) Phenolic content and antioxidant activity of four date palm (Phoenix dactylifera L.) fruit varieties grown in Tunisia. Int J Food Sci Technol 44(11):2314-2319

Santini A (2018) The importance of referencing. J Crit Care Med 4(1):3-

Shahdadi F, Mirzaei HO, Garmakhany AD (2015) Study of phenolic compound and antioxidant activity of date fruit as a function of ripening stages and drying process. J Food Sci Technol 52(3): 1814-1819

Siahpoosh A, Javedani F (2012) Antioxidative capacity of Iranian Citrus deliciosa peels. Free Radicals Antioxid 2(2):62-67

Siahpoosh A, Asili J, Sarhangi B (2016a) Antioxidative and free radical scavenging activities of some extracts from ripe fruits of Phœnix dactylifera L. Int J Pharmacogn Phytochem Res 8(10):1735-1741

Siahpoosh A, Taleb AM, Almasi H (2016b) In vitro evaluation of antioxidant activity and total phenol contents of some extracts from ripe fruits of Phoenix dactylifera var Berhi. Int J Pharmacog Phytochem Res 8:1855-1862

Siddhuraju P, Becker K (2003) Studies on antioxidant activities of mucuna seed (Mucuna pruriens var utilis) extract and various nonprotein amino/imino acids through in vitro models. J Sci Food Agric 83(14):1517-1524

Singh V, Guizani N, Essa MM, Hakkim FL, Rahman MS (2012) Comparative analysis of total phenolics, flavonoid content and antioxidant profile of different date varieties (Phoenix dactylifera L.) from Sultanate of Oman. Int Food Res J 19(3):1063

Singleton VL, Rossi JA (1965) Colorimetry of total phenolics with phosphomolybdic-phosphotungstic acid reagents. Am J Enol Vitic 16(3):144-158

Souli I, Jemni M, Rodríguez-Verástegui LL, Chaira N, Artés F, Ferchichi A (2018) Phenolic composition profiling of Tunisian 10 varieties of common dates (Phoenix dactylifera L.) at tamar stage using LC-ESIMS and antioxidant activity. J Food Biochem 42(6):e12634

Tang ZX, Shi LE, Aleid SM (2013) Date fruit: chemical composition, nutritional and medicinal values, products. J Sci Food Agric 93(10): 2351-2361

Tricco AC, Lillie E, Zarin W, O'Brien KK, Colquhoun H, Levac D et al (2018) PRISMA extension for scoping reviews (PRISMA-ScR): checklist and explanation. Ann Intern Med 169(7):467-473

Zhishen J, Mengcheng T, Jianming W (1999) The determination of flavonoid contents in mulberry and their scavenging effects on superoxide radicals. Food Chem 64(4):555-559

Publisher's Note Springer Nature remains neutral with regard to jurisdictional claims in published maps and institutional affiliations. 